\title{
Discourse particles, clause structure, and question types ${ }^{1}$
}

\author{
JOSEF BAYER and HANS-GEORG OBENAUER
}

\section{Abstract}

Discourse particles provide important clues to our understanding of the syntax-to-discourse relation. They are sensitive to sentence types and utterance contexts. As such they seem to contribute to the determination of illocutionary force. After providing some general background information on discourse particles, the present article focuses on the role of discourse particles in German constituent questions. Syntactic evidence is provided which suggests that they are pre-VP functional heads which can to some extent be stacked. It is shown how the particles under consideration can access the force system, and how this access can proceed even in cases in which they occur in embedded clauses. After providing the basic architecture, we investigate the role of these particles in "special questions", questions which are not interpreted as simple requests for information. The syntactic discussion is then extended to cases in which the discourse particle forms a constituent with a wh-phrase[wh+Prt] - , as well as to cases in which this constituent interacts with particles in pre-VP position. The [wh+Prt] construction offers important evidence both in favor of the head status of the particles under investigation and in favor

1. We are grateful to Ellen Brandner, Anne Breitbarth, Anna Cardinaletti, Probal Dasgupta, Franziska Hack, Liliane Haegeman, Sibansu Mukhopadhyaya, Cecilia Poletto, Volker Struckmeier, Sten Vikner and two anonymous reviewers for their comments, to the editors of this special issue, to Daniel Bürkle for editorial assistance, and very much also to Harry van der Hulst for his assistance. We also wish to thank the audiences of the Workshop on Particles, Cambridge, 30-31 October 2008 and of the Workshop The fine structure of clause types (Fédération Typologie et universaux linguistiques/TUL, CNRS), Paris, 28-29 November 2008. The usual disclaimers apply. The two authors were members of the research program Clause Types - Cartography and Typology (2006-2009) of the Fédération TUL, which has supported this research. We also received support from the Konstanz SFB 471 which is gratefully acknowledged. 
of the existence of distinctive syntactic properties of special questions, especially so-called "surprise-disapproval questions". Finally, data on surprisedisapproval questions in a Northern Italian dialect as well as in an Indo-Aryan language suggest that the findings about special questions in German are likely to fall under cross-linguistic generalizations.

\section{Introduction}

Discourse particles are something relatively new on the agenda of formal linguistics (although there has been much work in other frameworks of linguistic research, mainly related to pragmatics and conversation). Thus, before we launch into the discussion of their formal syntactic properties, we would like to give some background, especially on discourse particles in German as these elements (also known as "modal particles" or "Abtönungspartikeln") have received much attention in German linguistics. The research dates at least back to Georg von der Gabelentz (1917) and has been continued by various researchers whose contributions we cannot discuss here for reasons of space and the focus of the work to be presented below. Useful recent discussions of German discourse particles from a syntactic perspective can be found in Coniglio (2005; 2008). According to Thurmair (1997), the language has roughly 20 such particles. Consider as a typical example (1b).

(1) a. Wo wohnst du?
where live you
'Where do you live?'
b. Wo wohnst du denn?
where live you DENN
'Where do you live? (I am wondering)'

The difference between (1a) and (1b) is subtle but clear. While (1a) is a plain information-seeking question which does not reveal any attitude of the speaker, (1b) signals that the speaker is in a particular way "concerned" about the proposition that the answer would yield. The particle denn, related to English then, signals reference to some common ground between speaker and hearer beyond the presupposition of (1a). No existence of such an additional common ground is assumed in (1a). This is the reason why questions of type (1b) are often perceived as "more intimate" or "friendlier" than those of type (1a). It is a general property of discourse particles that they modify the utterance rather than the proposition. They express the speaker's attitude about him-/herself or about the hearer with respect to the propositional content of the utterance. As such, discourse particles belong to the vocabulary of "expressive" rather than "de- 
scriptive" meaning. ${ }^{2}$ Although the present work will primarily be concerned with the syntax of discourse particles, this property is of central importance. The reason is that the syntax has to specify in which way these particles contribute to the force of the root clause (utterance). Discourse particles in German usually occur in what is known as the "middle field" and, as we will see, even in embedded clauses. Thus, the question of their access to the syntactic representation of force is far from trivial.

The special role that discourse particles play in the grammar has, of course, left various formal reflexes which have been described by previous research. We will run through these properties as far as they are relevant for the aspects of particles to be looked at more closely in the present work. ${ }^{3}$

(i) Discourse particles are often adverbial in nature but show clearly distinct properties as will be shown below.

(ii) Unlike adverbs, discourse particles are usually immobile. They can neither be moved to designated landing sites (such as SpecCP) nor extraposed. ${ }^{4}$

(iii) Discourse particles normally cannot bear stress. ${ }^{5}$

(iv) Discourse particles mostly have counterparts to which they are historically related. They are the result of grammaticalization. ${ }^{6}$

(v) Discourse particles are in their typical occurrences mono-syllabic. German has bloß, denn, doch, halt, ja, nur, schon, wohl, but also "exceptions"

2. For recent discussion of expressive meaning in formal semantics cf. Kratzer (1999), Potts (2005) and Potts et al. (2009).

3. For a concise overview of their syntactic properties cf. Cardinaletti (2007).

4. Consider the following minimal pair involving two uses of the adverb/particle vielleicht 'perhaps':

(i) Vielleicht ist der Hans ein Zauberer. (vielleicht as a sentence adverb) perhaps is the Hans a magician

'Hans is perhaps a magician.'

(ii) Der HANS ist vielleicht ein Zauberer!

'What a great/lousy magician Hans is!'

(vielleicht as a discourse particle)

(i) is unambiguous and allows either Hans or Zauberer to bear the focal accent. (ii) is ambiguous between (i) with focus on Hans and an exclamative by which the speaker expresses that he/she takes Hans to be either a great or a lousy magician.

5. The obligatory stress on the particle $j a$ 'yes' in imperatives like Mach JA keinen Unfug! 'Don't you make any mischief!' is a notable exception, next to certain other cases which are not relevant here.

6. Cf. Abraham (1991; 2000), Bayer (2008), Diewald (1997), Hentschel (1986), Wegener (2002) among others. 
such as vielleicht, aber, eben, etwa. The latter are historically younger and may not have been fully reanalyzed yet. ${ }^{7}$

(vi) Discourse particles are modificational and as such appear to be "optional". 8

(vii) Due to their sensitivity to sentence types and their impact on illocutionary force, discourse particles are generally confined to root-clauses. ${ }^{9}$ It is well known, however, and will be discussed in detail below, that there are exceptions which require an explanation.

We will occasionally refer back to these general properties but will now turn to our actual topic. In doing so, we will narrow our view down to discourse particles in constituent questions.

The article is organized as follows: Section 2 offers a discussion of discourse particles in German wh-questions, their semantic contribution (Section 2.1), their syntactic position to the immediate left of the VP (Section 2.2) and their ability to co-occur in one and the same clause (Section 2.3). After that, it will be argued in 2.4 that discourse particles should be analyzed as a special sort of syncategorematically introduced functional heads. The topic of Section 2.5 is the syntactic communication between the force system of the clause and the discourse particles which contribute to the former. In Section 2.6 we present and explain data that show discourse particles in dependent clauses. Section 3 deals with the role of discourse particles in special questions, i.e. questions which express certain extra attitudes of the speaker as in rhetorical questions and in questions of irritation or surprise. In Section 4 we turn to data in which a discourse particle - exceptionally - forms a constituent with a wh-phrase, a

7. As Coniglio (2005) points out, vielleicht is reduced to the mono-syllabic leicht in Austrian dialects in cases where it is used as a discourse particle rather than as an adverb. Cf. Grosz (2005) for examples of the use of leicht in Viennese. We consider items which behave like discourse particles but lack their typical morpho-phonological shape as being in a state of transition.

8. The claim that they are optional must be taken with caution. First, there are a few cases in which the particle is obligatory.

(i) Peter hat frei, hat er *(doch) letzte Woche viele Überstunden Peter has free has he DOCH last week many over-hours gemacht.

made

'Peter has some free days because he worked many extra hours last week.'

Secondly, as will be shown in this article, particles play a constitutive role in the formation of special questions. Therefore, calling them optional would at best be misleading.

9. Although the notion of "force" is often used for dependent clauses which are not utterances (cf. Rizzi 1997), it should be clear that we stick to the narrower notion by which force is illocutionary force and as such only defined for utterances. 
constituent we will call "small PrtP". In Section 5 we discuss cases of mixed constituency, i.e. cases in which "small PrtP" co-occurs with the regular preVP PrtP. In Section 6 we take a closer look at special questions. In Section 7 we will briefly point to the fact that aspects of the syntax of special questions as it appears to exist in German can also be found in other languages, as shown here for the Northern-Italian dialect of Belluno and for the Indo-Aryan language Bangla (also known as Bengali). Section 8 contains a conclusion.

\section{Discourse particles in German wh-questions}

In the following, we will consider four particles which appear in German whquestions: denn (literally 'then'), nur (literally 'only') - and its near-equivalent blo $\beta$ (literally 'barely') - and schon (literally 'already'). ${ }^{10}$ The pertinent questions are the following: (i) What is the function of discourse particles in wh-questions? (ii) How can their role in the shaping of illocutionary force be accounted for? Our focus will be on the syntactic side but it goes without saying that the argumentation will involve questions of semantic and pragmatic interpretation at every point.

\subsection{Semantic contribution}

As noted above, the particle in each case adds a certain so-called "expressive" meaning to the question. Most researchers agree that these particles affect the level of utterance (illocutionary force) rather than the propositional level. Georg von der Gabelentz (1891) says in chapter 4 in a section about "Die Subjectivität", "When I insert [these particles, JB, HGO] into my speech, the reason for doing so cannot be immediately found in the subject matter of my speech but rather in an emotional need of the speaker." Thurmair (1989) suggests semantic features most of which pertain to a special context dependence, to previous discourse or to the state of knowledge of the interlocutors. Work in formal semantics (cf. Jacobs (1991), Kratzer (1999; 2004), Zimmermann (2004), Potts (2005) and various others) agrees with this insight, analyzing discourse particles as elements which play a role when sentence types (declaratives, interrogatives, imperatives, optatives etc.) connect to discourse and as such to the interlocutors and their contextual knowledge. They make a noticeable semantic contribution which, however, concerns "expressive"

10. These translations need to be viewed with caution. They concern the "descriptive meaning". Although there are reasons to believe that this meaning is related to the "expressive meaning" of the discourse particles, the latter cannot be identified via these translations. 
rather than "propositional" meaning, and which is often difficult to spell out very precisely. According to Kratzer (2004), "[ . . ], the composition of descriptive meanings is blind to any expressives in their syntactic scope. Descriptive and expressive content must be separated, suggesting a multi-tiered semantics." "11 Constituent questions like (1a) are syntactically derived and step-wise semantically interpreted, with indexicals such as the 2. person singular pronoun referring to the addressee, present tense anchoring to question in the speech time etc. In (2) through (4), the discourse particles under consideration - denn, nur/bloß, schon - have been added to constituent questions. Their semantic contribution is indicated in parentheses. ${ }^{12}$

(2) Wo hast du denn meine Schlüssel hingelegt? where have you DENN my keys put-down 'Where did you put my keys? (I'm wondering)'

(3) Wo hast du nur / bloß meine Schlüssel hingelegt? where have you NUR/ BLOSS my keys put-down 'Where did you put my keys (I have already looked everywhere)?'

(4) Wer zahlt schon gerne Steuern? who pays SCHON gladly taxes "Who likes paying taxes? (Nobody!)"

Due to the discourse particle, these questions are either more than informationseeking questions or even no information-seeking questions at all. (2) and (3) express something about the mental state of the speaker that goes beyond the actual erotetic act. (4) gives rise to an implicature according to which hardly anybody or even nobody at all is such that the predicate applies to him or her. We will return to the semantics of these particles in Section 3. For the time being it should suffice to say that denn (diachronically related to the anaphoric dann 'then') signals that the speaker is a) concerned about the answer, and b) assumes that the hearer shares knowledge with him on the basis of which he or she can expect him/her to provide a relevant answer. This excludes out-of-theblue denn-questions. Imagine I ask an arbitrary passenger in some city $\mathrm{X}$ Where is DENN the train station?, my assumption being that the passenger knows that we are in $X$, and that $X$ is likely to have at least one train station. The same speech act would fail if I ask Where is DENN the station in Y?, Y being a place that the addressee cannot be assumed to be acquainted with. On the other hand,

11. Expressives in the narrow sense are predicates like damn, bloody, fucking etc. (cf. Potts et al. 2009). They must be distinguisted from discourse particles. Nevertheless, the latter contribute to expressive meaning as well.

12. At this informal level, no distinction is made between the actual meaning and implicatures that arise from it. 
I could well ask Where is the station in Y?, say, in order to test the topographical knowledge of people in a contest or quiz etc. Here denn would be inappropriate as there is no common ground between me and the addressee concerning the location of the train station in $\mathrm{Y} .{ }^{13} \mathrm{Nur} / \mathrm{blo} \beta$ are related to the homophonous focus particles with the eliminative semantic impact of only. In (3) these particles signal that the speaker has tried a number of times to find a value for the wh-variable, but without success. Schon in (4) corresponds to the temporal adverb for already. Its semantic impact as a discourse particle is that it turns the question into a rhetorical question. In this case, an answer is actually not expected because it is already provided by an implicature.

We will return to the semantics of the particles under consideration in Section 3 where the focus will be more closely on special questions like (2)-(4).

\subsection{Position}

Discourse particles occupy a position below the landing site of the finite verb Fin $^{\circ}$ (related to $\mathrm{C}^{\circ}$ in comp-clauses) and the higher (speech act, evaluative, evidential, epistemic etc.) adverbs. Although they are utterance/force oriented, they are positioned as low as at the left edge of $\mathrm{VP} / v \mathrm{P}$. They are obligatorily preceded by weak and clitic pronouns (cf. [5], [6]), and optionally preceded by topical elements (definite DPs, indefinites with a generic rather than an existential interpretation, stage setting adverbs and PPs etc.). These topical elements can also include contrastive topics. ${ }^{14}$ In the examples, capitals indicate focus. (5) and (6) are disjunctive questions in which denn is suitable whereas $n u r \mid b l o \beta$ and schon qua discourse particles would be out.

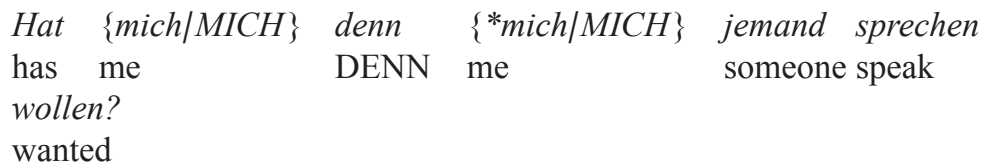

'Did someone want to talk to me? (I am wondering)'

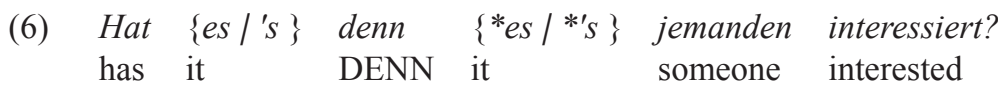

'Did someone take an interest in it (. . )?'

13. For other examples and further discussion cf. König (1977), Wegener (2002) and Bayer (2008).

14. The data do not satisfactorily discriminate between aboutness topics in the sense of Reinhart (1981) and general discourse-introduced thematic elements. 
(7) through (10) show that the space between the finite verb and the particle nur can in principle remain empty but is often filled by definite DPs or PPs with a definite DP or stage setting adverbs.

(7) Wann könnte nur Otto den Brief gestern ins Büro when could NUR Otto the letter yesterday to office mitgenommen haben?

along-taken have

'When could Otto have yesterday taken the letter to the office? (I've found no answer so far)'

(8) Wann könnte Otto nur Otto den Brief gestern ins Büro mitgenommen haben?

(9) Wann könnte Otto den Brief nur Otto den Brief gestern ins Büro mitgenommen haben?

(10) Wann könnte Otto den Brief gestern nur Otto den Brief gestern ins Büro mitgenommen haben?

(11) Wann könnte Otto den Brief gestern ins Büro nur Otto den Brief gestern ins Büro mitgenommen haben?

Discourse particles require information focus to their right, ( $\mathrm{MICH}$ in (5) is not information but contrastive focus). Movement out of the scope of the particle shrinks the focus domain. Thus, (11) retains only the verb mitgenommen in the focus domain such that the example comes out as Wann könnte Otto den Brief gestern ins Büro nur MITGENOMMEN haben? Indefinites with an existential interpretation must remain in the scope of the particle as shown in (12) and (13).

(12) Wo kannich nur einen Kaugummi kaufen?

where can I NUR a chewing-gum buy

'Where can I buy chewing gum? (I have no idea)'

(13) *Wo kann ich einen Kaugummi nur einen Kaugummi kaufen?

Indefinites with a generic interpretation as in (14) are potential topics and can occur outside the scope of the particle.

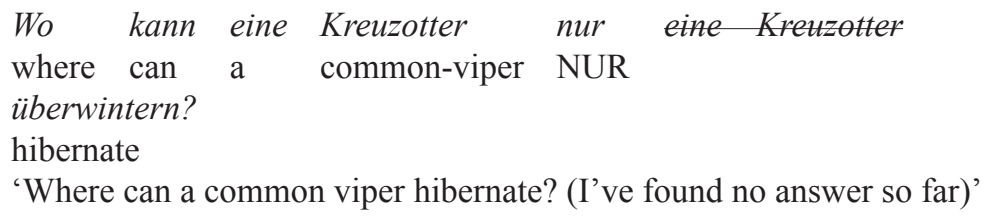

These facts echo Diesing's (1992) generalization according to which the discourse particle marks the $v \mathrm{P}$-boundary and determines that an indefinite in its scope remains in $v \mathrm{P}$ where it is subject to existential closure. 


\subsection{Stacking}

Discourse particles can be stacked, and if they are, the particles usually appear in fixed order. ${ }^{15}$ Combinations with up to three adjacent particles can easily be found. ${ }^{16}$ In wh-questions, denn - being the highest particle - must precede nur|bloß or schon.

(15) Wo bist $d u$ denn nur / blo $\beta$ den ganzen Tag where are you DENN NUR/ BLOSS the whole day gewesen?

been

'Where on earth have you been the entire day (I am wondering)?'

(16) *Wo bist du nur/bloß denn den ganzen Tag gewesen?

(17) Wer zahlt denn schon gerne Steuern?

who pays DENN SCHON gladly taxes

'Who likes to pay taxes? (Nobody!)'

*Wer zahlt schon denn gerne Steuern?

Particle stacking in fixed order could invite the idea of a lexically reanalyzed "super particle", but this trivialization of the matter is incompatible with the fact that the particles can also be non-adjacent. Topical material such as seen in (7) through (11) can freely be moved to the immediate left of each of those particles; see (19), a different version of (15), or the more complex example in (20) in which the particle wohl appears in addition to denn and nur/bloß (also cf. note 16).

(19) Wo bist du denn den ganzen Tag nur/bloß du den ganzen Tag gewesen?

15. Exceptions are halt and eben. They can appear in any order.

16. Cf. the sequence denn $<$ wohl $<$ etwa in disjunctive questions, as in

(i) [...] und ist denn wohl etwa das Genie wirklicheine [...] and is DENN WOHL ETWA the genius really a zusammengesetze Mixtur, [...]

composed mixture

'and is in this case the genius really a blend' (it surely is not)

C.G. Carus (1831), Vorlesungen über Psychologie. Leipzig. Verlag Gerhard Fleischer

or in declaratives $j a<$ doch $<w o h l$ as in

(ii) Die Verantwortung haben ja doch wohl die Moderatorinnen the responsibility have JA DOCH WOHL the presenters

'Responsibility, as you know, lies almost certainly with the presenters' http://www.heim.sozialpsychiatrie.de/?q=node/13 (10-10-2009)

On various functions of wohl (related to Engl. well), cf. Zimmermann (2004). 
(20)

Wo könnte Otto denn gestern wohl den Brief
where could Otto DENN yesterday WOHL the letter
nur I bloß Otto gestern den Brief abgegeben haben?
NUR/ BLOSS
'Where could Otto have delivered the letter yesterday?'

\subsection{Phrase structural status}

There is controversy about the X-bar status of discourse particles, cf. Meibauer (1994). Some researchers assume they are adverbs, albeit of a special impoverished kind; cf. Cardinaletti (2007; this volume), Coniglio (2005: §4.1), Grosz (2005). The controversy extends also to the status of focus particles. Following Jacobs (1983), Büring and Hartmann (2001) argue that German focus particles are adverbs which can only combine with verbal projections. Bayer (1996) argues in favor of head status. We will present new evidence in favor of the latter view in Section 4.

A number of properties suggest that at least the discourse particles under consideration have the status of functional heads. Properties mentioned in Section 1 such as immobility (cf. ii), phonological shape (cf. iii and v) and grammaticalization (cf. iv) are compatible with head status without extra assumptions. These facts are uncontroversial. So what is the motivation for the rejection of the head-analysis? The central (and perhaps sole) argument has been that a head-type particle would interfere with V2 because of the HeadMovement Constraint (HMC). ${ }^{17}$ The easiest answer would be to argue that V2 is not head-movement. Following Müller (2004), one could try to argue along these lines. In an attempt to argue against head movement in general, Müller proposes that German V2 is actually remnant $v \mathrm{P}-$ movement. According to Müller's analysis, SpecCP and $\mathrm{C}^{\circ}$ are even a single constituent. The presumed reason is that all material but the finite verb and something that is a possible $v \mathrm{P}$-edge have been removed from $v \mathrm{P}$. The classical two-step analysis of $\mathrm{V} 2$ as finite-verb fronting plus topicalization or wh-movement to SpecCP is by this analysis declared to have been misguided. Although $\mathrm{V} 2$ as $v \mathrm{P}$-movement in disguise would immediately solve the apparent minimality conflict, we will not follow this path. ${ }^{18}$ We would rather argue that even under conventional assumptions there is no reason for head-movement style V2 to interfere with intermediate heads such as those represented by discourse particles or focus

17. Travis' (1984) HMC states that head-movement must not skip intermediate heads.

18. There are independent reasons not to do that. Müller's reanalysis divorces itself from central diachronic insights about X2 that stem from Wackernagel (1892) and have been lucidly taken up in Anderson (1993). For independent criticism cf. Fanselow (2004) and Lechner (2009). 
particles. On the empirical side, no intermediate landing of the finite verb in a purported particle-related head position can be observed. It would amount to something like (21a) with the analysis in (21b) in which denn occupies the specifier of a particle phrase (PrtP).
a. *Er denn ist gestern hier gewesen ist he DENN is yesterday here been
b. $* E r\left[{ }_{P r t P}\right.$ denn $\left[{ }_{\text {Prt }}{ }^{\prime}\left[{ }_{\text {Prt }}^{\circ}\right.\right.$ ist $]$ gestern hier gewesen ist $\left.]\right]$

Such cases of stop-over are unattested in the grammar of German. Secondly, there is good evidence that in modern German and its dialects nicht 'not' is a functional head which attracts negatively marked indefinites ("NegQPs") to its specifier. ${ }^{19}$ However, neither does the head nicht inhibit V2 nor does it move along with the verb. With respect to particles, more evidence for their head status will be presented in Section 4.

Closer inspection reveals that on more general grounds there is no reason either for discourse particles, focus particles or negation to interfere with V2. To see this, consider the special character of particles and similar heads: They do not project categorial features. A $v \mathrm{P}$ which has been merged with a particle or with the neg-head remains a $v \mathrm{P}$ in categorial terms. Although these elements

19. Cf. Weiß (2002) on negation in Bavarian. Until recently, German allowed negative concord quite regularly. A negatively marked indefinite moves to the specifier of a $\mathrm{NegP}$ which is headed by nicht.

(i) weil das kein Mensch nicht macht
because this no man not does
'because nobody does that'

If both the negative quantifier and nicht are specifiers of a zero-headed NegP, it is difficult to account for the word order, the order nicht $<$ kein Mensch being ungrammatical. If nicht is a head, this question of order does not arise. From the perspective of diachrony and grammaticalization it is expected that after the loss of pre-verbal negation en- the dependent DP ni-owiht ("no-at all-thing"), which underlies modern nicht, has been reanalyzed as a head. Nevertheless, there is evidence that nicht retains a dual X-bar status as it can exceptionally appear in SpecFinP, mainly in archaic styles.

(ii) Nicht habe ich gesessen bei falschen Leuten, und mit Hinterlistigen not have I sat with wrong people and with perfidious

ging ich nicht um

went I not around

'I did not sit with wrong people, and I did not deal with perfidious ones'

\{Psalm.1,1\} http://www.bibel-online.net/bibel_1_3/19.psalmen/26.html

As such it is understandable that the debate about the X-bar status has remained controversial. Cf. Jäger (2005), Zeijlstra (2004), and Barbiers (2002) for Dutch. In all the writing, however, the central argument against head status of nicht has been its alleged incompatibility with the HMC. 
introduce semantic features, they fail to introduce categorial syntactic features. Their syncategorematic character puts them in the vicinity of adverbs. With different cases in mind, Rothstein (1991) suggests the label "minor functional head" (MFH). MFHs lack a theta-grid and do not project categorial features. For us it is important that particles are MFHs due to the fact that they do not project categorial features. Consider now Matushansky's (2006) recasting of the HMC in a strictly derivational system. She proposes the condition in (22).

\section{Transparency Condition}

A head ceases to be accessible once another head starts to project.

In the spirit of Rizzi's (1990) Relativized Minimality we may reformulate the $\mathrm{TC}$ in a more restrictive sense as in (23).

\section{(23) Transparency Condition (restrictive version)}

A head with the categorial feature $\mathrm{X}$ ceases to be accessible once another head $\mathrm{Y}$ starts to project its own categorial feature.

The amendment in (23) declares heads which are introduced syncategorematically to be non-interveners for reasons of absence of categorial projection. Particles as well as the head of negation in German, nicht, are by definition noninflecting and category-neutral. After merger with some phrase ZP, they impose their semantic features on the resulting category but leave ZP's categorial features unchanged. The finite verb that moves to $\mathrm{C}^{\circ}-$ in our terms actually Fin ${ }^{\circ}$ - is of course different in that upon movement it projects FinP (alias "CP"). Thus, particles do not interfere with V2 as they are - according to (23) invisible to the verb.

On the basis of these considerations and additional evidence that will be presented in Section 4 below, we suggest that discourse particles are functional heads, albeit MFHs in the sense of Rothstein (1991). Although MFHs do not project their own syntactic categorial features, we will for convenience use the label "particle phrase" (PrtP). Thus, Prt is merged with $\mathrm{VP} / v \mathrm{P}$ and projects a PrtP such that PrtP is semantically and phonologically distinct from VP/vP but identical with $\mathrm{VP} / v \mathrm{P}$ in terms of its syntactic features. ${ }^{20}$

\subsection{Feature valuation}

Recall now that the particles under consideration, denn, nur, bloß, schon, arise in questions, in fact - as the presently relevant common denominator - in wh-

20. In terms of bare phrase structure, the proposal amounts to $\{\langle\mathrm{V} / v, \mathrm{~V} / v\rangle,\{\operatorname{Prt},\{\mathrm{V} / v \ldots\}\}\}$, which is indistinguishable from an adjunction structure in which Prt would be non-projecting and thus equivalent to XP. One may add to Prt a label that declares it to be a head. Trying to overcome this stipulation would take us far beyond the scope of this article. 
questions. Discourse particles are by definition dependent on clause types (cf. property (vii) in Section 1). For the particles under discussion, this can be expressed by a feature of interrogativity (Q- or wh-). We assume that in the German root clause the finite verb appears in $\operatorname{Fin}^{\circ}\left(\right.$ alias $\mathrm{C}^{\circ}$ ), and that it activates illocutionary force right there. The assumption is thus that the V2-FinP coincides with ForceP. ${ }^{21}$ The phrase structure of a wh root clause with a question sensitive discourse particle is then roughly as in (24).22

$$
\left[\text { FinP/ForceP Wh Force } / \text { Fin }^{\circ}\left[(\mathrm{TopP}) \cdots\left[\mathrm{PrtP} \operatorname{Prt}^{\circ}\left[\left(\mathrm{AdvP}^{*}\right)[\mathrm{vP} / \mathrm{vP} \ldots]\right]\right]\right]\right.
$$

The discourse particle clearly affects the interpretation of the wh-clause by adding a special speaker/hearer based context condition. It is a big open question how the grammar takes care of the relation between Force ${ }^{\circ}$ and $\mathrm{Prt}^{\circ}$. An idea that can be discarded right away is that PrtP is part of a split ForceP. As we shall see in the next section, PrtP can appear at a big enough distance from the force head to preclude this option. With respect to the German particle wohl, Zimmermann (2008), who takes wohl to be an adverb, argues in favor of LFmovement to SpecFocP. According to him, "ForceP $[\ldots$. . encodes the strength of the propositional commitment [ ...]. This modification in the strength of commitment can be brought about by modifying expressions in the specifier of ForceP." LF-movement in the sense of covert movement not being an option in minimalist syntax, one can try to reach this goal in terms of either feature movement (Chomsky 1995) or the agreement mechanism that has been proposed in Chomsky $(2000 ; 2001)$ and subsequent work. Let us try out the second one: probe/goal agreement. The current minimalist standard proposal sees the probe as a head with a non-interpretable (-int) feature and the goal with a matching interpretable (+int) feature. Given c-command and no other intervening potential goals, agreement between probe and goal deletes the probe's -int feature and disables the goal from undergoing further agreement. Applying this part of the theory directly to the case at hand would require a particle-specific -int feature in Force ${ }^{\circ}$ which probes PrtP. Notice, however, that interrogative force is independent of the appearance of a discourse particle. The particle contributes to interrogative force once it is present but it does not constitute interrogative force. Following the semantic reasoning of Zimmermann, the way to go would rather be to search for a mechanism that supplies the Prt-

21. Since V2 in German does not provide empirical reasons to assume more than a single head position for the finite verb, we assume that FinP and ForceP are collapsed in the sense of Giorgi and Pianesi's (1997) option of feature bundling. In the present context, nothing hinges on this assumption though.

22. The assumption that higher adverbs - signaled here with a Kleene star - always follow discourse particles is surely a simplification, cf. Coniglio (2005), but for reasons of space we have to leave the details of this issue aside here. 
features to ForceP with the result that the force of the utterance is fine-tuned in some way. A theory of feature valuation and interpretability that seems to be suitable is the one suggested by Pesetsky and Torrego (2007). Pesetsky and Torrego propose a version of probe/goal agreement which is based on feature sharing. We will first introduce their proposal and then move to an extension that seems to us to account for the syntax of discourse particles in questions.

\subsubsection{Pesetsky and Torrego (2007)}

Pesetsky and Torrego (2007), henceforth PT, start from and subscribe to Chomsky's $(2000 ; 2001)$ suggestion according to which an unvalued feature (the "probe") on a head H scans its c-command domain in search of another occurrence of $\mathrm{F}$ (the "goal") with which it can agree. If the goal has a value, its value is assigned to the value of the probe. Features can be interpretable or uninterpretable. According to Chomsky (2001), (25) holds.

(25) A feature $\mathrm{F}$ is uninterpretable iff it is unvalued.

PT reject (25) and propose an alternative theory which takes agreement to be feature sharing and divorces agreement from feature valuation/deletion. They suggest the version in (26).

(26) Agree (feature sharing version)

(i) An unvalued feature $\mathrm{F}$ (a probe) on a head $\mathrm{H}$ at syntactic location $\alpha(\mathrm{F} \alpha)$ scans its c-command domain for another instance of $\mathrm{F}$ (a goal) at location $\beta(\mathrm{F} \beta)$ with which to agree.

(ii) Replace $\mathrm{F} \alpha$ with $\mathrm{F} \beta$, so that the same feature is present in both locations.

Their version of agreement is silent about interpretability. It allows in addition to interpretable and valued features and uninterpretable and unvalued features as they are predicted in Chomsky's theory also uninterpretable and valued features as well as interpretable and unvalued features. Agreement between two unvalued occurrences of $F \alpha$ and $F \beta$ is possible because the result is a single $F$ (with two instances). ${ }^{23}$ This unvalued $\mathrm{F}$ must be valued by subsequent agreement with a valued $\mathrm{F} \gamma$ in order to satisfy the standard assumption that an uninterpretable feature must be valued and deleted for convergence in the C-I interface. PT's approach is free of the directionality requirement by which the probe always has the uninterpretable and the goal the interpretable feature. There are

23. This should answer the question of one of the reviewers who asked why the probe should acquire an uninterpretable, i.e. unvalued feature at all. PT's feature sharing account is clearly different from Chomsky's uni-directional feature assignment account. PT refer to Brody's (1997) concept of Radical Interpretability. Brody suggests that each feature is interpretable somewhere in syntactic structure, not necessarily in a specific domain. 
instances where the opposite appears to be the case. In a CP in which whmovement applies, $\mathrm{C}^{\circ}$ is endowed with an interpretable although unvalued Q-feature (in PT's notation " $i \mathrm{Q}[$ ]") by which it agrees with a wh-phrase that bears an uninterpretable although valued interrogative Q-feature (in PT's notation " $u \mathrm{Q}+$ interrog"). ${ }^{24}$ If $\mathrm{C}^{\circ}$ has the uninterpretable and unvalued feature $u \mathrm{Q}[$ ], it can nevertheless undergo agreement with a wh-phrase marked $u \mathrm{Q}+$ interrog. At the edge of the resulting $\mathrm{CP}, \mathrm{C}^{\circ}$ will be valued but still remain uninterpretable: $u \mathrm{Q}+$ interrog. For the derivation to converge, this feature must ultimately agree with and value a feature $i \mathrm{Q}[\mathrm{]}$. The processes just described account naturally for single-clause wh-movement and cyclic wh-movement respectively. Agreement is expressed by an arbitrary value that fills the empty slot in [ ]. Thus, one-step wh-movement runs as in (27) where 6 is chosen as the arbitrary value, while (28) shows the first step of cyclic wh-movement with $\mathrm{CP}$ only an intermediate landing site for the wh-phrase.

$$
\begin{aligned}
& \ldots \mathrm{C}^{\circ} \quad \ldots \text { what } \ldots \quad==\mathrm{AGREE}==>\ldots \mathrm{C} \quad \ldots \text { what } \\
& i \mathrm{Q}[\mathrm{l} \quad u \mathrm{Q}+\text { interrog } \quad i \mathrm{Q}[6] \quad u \mathrm{Q}+\text { interrog[6] } \\
& \ldots \mathrm{C}^{\circ} \quad \ldots \text { what } \ldots \quad==\mathrm{AGREE}==>\ldots \mathrm{C} \quad \ldots \text { what } \\
& u \mathrm{Q}[] \quad u \mathrm{Q}+\text { interrog } \quad u \mathrm{Q}[\mathbf{6}] \quad u \mathrm{Q}+\text { interrog[6] }
\end{aligned}
$$

So far, $\mathrm{Q}$ is independent of force; $i \mathrm{Q}$ marks the final landing site of wh which may be the specifier of an embedded clause as in It is unclear [where she went]. Since the bracketed part is not an utterance, it arguably has no illocutionary force (cf. note 9). Once the wh-phrase accesses the root clause, it is in the specifier of ForceP/FinP. In the absence of further information, the default interpretation will be a plain information-seeking question. Since the discourse particles under consideration contribute to the force of a question, the syntax should express this. We will next explore what use can be made of PT's feature sharing account for the association of discourse particles with Force.

\subsubsection{Accomodating discource particles in Force}

Given that the particles under investigation are sensitive to the interrogative clause type in which they occur, we attribute to them the feature [QForce]. [QForce] is an unvalued uninterpretable feature which is valued by iQForce. $\mathrm{iQForce}$ is associated with the force/fin-head. According to our assumptions, force is a root property. Thus iQForce is associated with the Force ${ }^{\circ} /$ Fin $^{\circ}$ head of the root clause. Consider the simplest case (29) in which there is a single PrtP involved:

24. This view is empirically supported by (a) the comparative syntax of clause typing (cf. Cheng. 1991) and (b) by the related fact that in many languages the wh-pronouns are understood as indefinites unless they can hook up to Q (cf. Haspelmath, 2002 for a typological survey). 
(29)

$$
\begin{aligned}
& {\left[\text { FinP/ForceP Wh Force } / \text { Fin }^{\circ} i \mathrm{Q}, i \text { QForce [ }\right]\left[{ }_{(\mathrm{TopP})} \cdots \text { [PrtP } \operatorname{Prt}^{\circ}{ }_{u \text { QForce [ ] }}\right.} \\
& \left.\left.\left.\left[\left(\mathrm{AdvP}^{*}\right)[\mathrm{VP} / v \mathrm{P} \ldots]\right]\right]\right]\right]
\end{aligned}
$$

Agreement, as indicated in (30) by an arbitrary number, establishes the relevant link and ultimately allows the removal of the uninterpretable feature uQForce from the representation.

$$
\begin{aligned}
& {\left[\text { FinP/ForceP Wh Force } / \text { Fin }^{\circ} i \mathrm{Q}, i \text { QForce [4] }[(\mathrm{TopP}) \cdots\right.} \\
& \left.\left.\left[\left(\operatorname{AdvP}^{*}\right)[\mathrm{VP} / v \mathrm{P} \cdots]\right]\right]\right]
\end{aligned}
$$

The feature [Qforce] does not represent the individual particle. The mechanism does not move the particle. We will see in Section 5 that such a movement would be an undesirable result. There is also evidence from particle stacking that the particles take scope exactly where they appear in phrase structure. Thus, [QForce] must be seen as a cover feature that is associated with all the discourse particles which appear in the scope of the interrogative Force/Fin head. The agreement relation postulated seems to be the appropriate mechanism to allow the force head to reach down into the clause and integrate elements from lower functional projections to take part in the semantic shaping of illocutionary force.

The simultaneous dependency of stacked PrtPs on an interrogative Force/Fin can be expressed because each PrtP shares the goal feature with the other as well as with the probe, as seen in (31) and (32). ${ }^{25}$

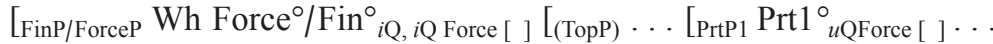

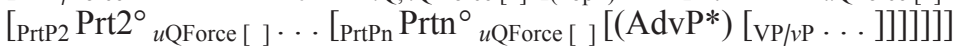

$$
\begin{aligned}
& {\left[\text { FinP/ForceP } W h \text { Force } ^ { \circ } / \text { Fin } ^ { \circ } { } _ { i \mathrm { Q } , i \mathrm { Q } \text { Force } [ 1 2 ] } \left[(\mathrm{TopP}) \cdots \text { [PrtP1 } \operatorname{Prt}{ }^{\circ}{ }_{u \text { QForce }}[\mathbf{1 2}] \cdots\right.\right.} \\
& \left.\left.\left.\left[\mathrm{PrtP} 2 \operatorname{Prt} 2^{\circ}{ }_{u \text { QForce [12] }} \ldots \text { [PrtPn } \operatorname{Prtn}_{u \text { QForce [12] }}^{\circ}\left[\left(\mathrm{AdvP}^{*}\right)[\mathrm{vP} / v \mathrm{P} \ldots]\right]\right]\right]\right]\right]
\end{aligned}
$$

In the next section, we will provide more empirical support for the phrase structure and feature valuation that has been developed so far.

\subsection{Discourse particles in dependent clauses}

Property (vii) in Section 1 has already mentioned the possibility of discourse particles occurring in embedded clauses. They can do so in embedded clauses which nevertheless allow a root interpretation (because they may count as re-

25. Since the particles as lexical entities are intrinsically ordered, there is no question whether one agrees with the other in terms of [QForce]. The feature [uQForce] is shared by all of them and gets valued simultaneously as soon as agreement with the probe is established. Thanks to Anne Breitbarth and Liliane Haegeman (p.c.) for bringing this issue to our attention. 
ported speech etc. as in Er will wissen, wann du denn jetzt kommst, "He wants to know when you DENN will come", with denn at the source of the citation effect). Interestingly, however, they can also appear in certain embedded clauses which do not allow a root interpretation. In particular, the question sensitive particles denn, nur, blo $\beta$ and schon can appear in dependent clauses which preclude an interrogative type because they are embedded under a propositional attitude verb. Consider (33) which was found on the internet. ${ }^{26}$

(33) Wie denkst du, dass es denn weitergehen soll mit how think you that it DENN go-on should with euch? you 'How do you think that the two of you should carry on? (I'm wondering)' http://mein-kummerkasten.de/142829/fremdgehen.html, 23.10.2009

The example's structure is roughly as in (34).

(34) Wie denkst du [ $\mathrm{CP}$ wie dass es $[\mathrm{PrtP}$ denn wie weitergehen soll mit euch]]?

The wh-phrase has been extracted from the $\mathrm{CP}$ in which PrtP occurs. This case contrasts strikingly with the ungrammatical (35) and (36). Their respective structures in (37) and (38) show that in these cases PrtP is located in a CP from which no wh-phrase has been extracted.

$$
\begin{aligned}
& \text { *Wer hat dir erzählt, dass Karl denn recht hat? } \\
& \text { who has you told that Karl DENN right has } \\
& \text { 'Who told you that Karl was right?' }
\end{aligned}
$$

$$
\begin{aligned}
& \text { *Wem hast du erzählt, dass Karl denn recht hat? } \\
& \text { whom have you told that Karl DENN right has } \\
& \text { 'Who did you tell that Karl was right?' } \\
& \text { *Wer hat wer dir erzählt }\left[{ }_{\mathrm{CP}} \text { dass Karl }\left[{ }_{\mathrm{PrtP}} \text { denn recht hat }\right]\right] \text { ? } \\
& \text { *Wem hast du wem erzählt } \left.\left.{ }_{\mathrm{CP}} \text { dass Karl }{ }_{\mathrm{PrtP}} \text { denn recht hat }\right]\right] \text { ? }
\end{aligned}
$$

The contrast between (33)/(34) and (35) through (38) suggests that Prt can occur in a dependent non-interrogative clause as a consequence of whmovement from that clause. (33) can be expanded as shown in (39) and (40).

26. We will in the rest of the article frequently rely on data from the internet because this is where the informal style of spoken languages can be found. Discourse particles occur mainly in spoken language. Carefully selected published examples may in addition help to overcome occasional disagreements about the data. 
(39) Wie denkst du, dass seine Mutter denn meint, dass

how think you that his mother DENN thinks that

es weitergehen soll mit euch?

it on-go should with you

'How do you think that is mother thinks that the two of you should carry on? (I'm wondering)'

(40) Wie denkst du ${ }_{\mathrm{CP}}$ wie dass seine Mutter ${ }_{\mathrm{PrtP}}$ denn meint ${ }_{\mathrm{CP}}$ wie dass es wie weitergehen soll mit euch]]]?

Prt could, of course, also arise in the lowest CP. (39)/(40) is, however, more interesting because it shows that the force feature of Prt can obviously be picked up by the wh-phrase in passing. ${ }^{27}$

The data and their structure in (33) through (40) show that the licensing of the discourse particle proceeds in steps that are familiar from cyclic whmovement. Probe/goal agreement cannot reach from the root clause down into the dependent CP. It rather applies within the CP-phase. ${ }^{28}$ This empirical result clearly supports the phase approach to syntactic derivations.

Applying the version of probe/goal agreement that has been introduced in Section 2.5, association of the CP's head dass with the feature uQForce is a consequence of the wh-phrase passing through SpecCP. The assumption is that the complementizer dass is $u \mathrm{Q}[\mathrm{]}$ as in (28), and that as a consequence of $u \mathrm{Q}\left[\right.$ ] it is also $u \mathrm{QForce}\left[\mathrm{]}\right.$. By the latter feature, $\mathrm{C}^{\circ}$ can agree with PrtP. Thus, (33) is derived via the steps shown in (41) and - after the root clause has been built - as continued in (42).

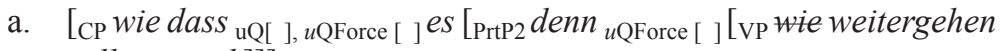 soll mit euch]]]

$$
\text { AGREE } \Rightarrow
$$

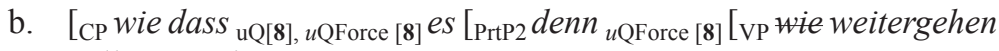
soll mit euch]]]

(42) a. $\quad\left[\right.$ FinP/ForceP Wie Force $^{\circ} /$ Fin $^{\circ}{ }_{i \mathrm{Q}}$, iQForce [ ] … [CP wie dass $\mathrm{uQ}[\mathbf{8}], u \mathrm{QForce}[8]$ es [ $\mathrm{PrtP}_{\mathrm{P} 2}$ denn ${ }_{u \mathrm{QForce}}[\mathrm{8}][\mathrm{VP}$ wie weitergehen soll mit euch]]]] AGREE $\Rightarrow$

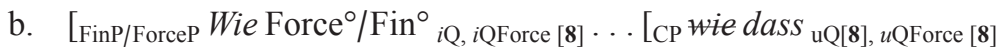
es [PrtP2 denn ${ }_{u \mathrm{QForce}[\mathrm{8}]}[\mathrm{VP}$ wie weitergehen soll mit euch $\left.\left.\left.]\right]\right]\right]$

27. Notice that the test can also be made with partial movement. Speakers who do not accept extraction from dass-CPs usually accept partial movement without any problem.

28. Due to its lack of a projecting syntactic category, PrtP is something like a "VP/vP extension". In that case it is unlikely to be an independent phase. But even if it were, $\mathrm{C}$ would be able to establish an agreement relation with its edge. 
The deviant status of the examples in (35) and (36) is predicted because denn appears in a CP which lacks uQ[ ] and uQForce[ ]. The feature uQForce[ ] on denn cannot be reached by the probing head Force ${ }^{\circ} /$ Fin $^{\circ}$ of the matrix clause. It has been spelled out with $\mathrm{CP}$ at the point in the derivation when Force $/$ Fin $^{\circ}$ is merged.

The fact that question-sensitive discourse particles like denn may materialize in dependent clauses which lack interrogative interpretation sheds new light on the organization of the "left periphery" of a split CP in the sense of Rizzi (1997). It is not simply the case that there are different layers of structure in a single clause which may include the force-relevant PrtP. PrtP may be arbitrarily far away from the left periphery of the matrix clause and still exert its semantic influence on the illocutionary force of the matrix clause. Given the standard analysis of successive cyclic movement, it is a trivial exercise to check how the system works in the case of intermediary PrtPs which are "crossed" by whmovement as in (39)/(40).

Our conclusion is in agreement with the bulk of previous research on German discourse particles, namely that the particles under investigation apply to the utterance level, i.e. to the force system of the CP. Nevertheless, discourse particles can be at an arbitrary distance from the root's force projection as long as PrtP can make contact with the Force/Fin head via derivation in phases. According to the present account, the particle does not undergo LF-movement or the like; it is rather the case that PrtP is part of a local agreement relation which is established as a consequence of successive cyclic movement through the specifier of $\mathrm{CP}$ which minimally dominates PrtP.

\section{Particles in special questions}

In German, discourse particles in questions regularly - and sometimes more or less obligatorily - appear in the three interrogative subtypes which Obenauer (2004) calls "Surprise-Disapproval Questions" (SDQs), "Can't-Find-theValue-of- $x$ Questions" (CfvQs), and rhetorical questions (RQs) respectively. ${ }^{29}$ (43) and (44) are examples of SDQs (signaled by the punctuation "?!"), with (44) a case of "why-like what", i.e. an SDQ in which the wh-pronoun was functions as an adjunct and acquires an interpretation close to, but not identical with that of why. ${ }^{30}$

29. In the Northern Italian dialect Pagotto (Bellunese) analyzed in Obenauer (2004), the same three interrogative subtypes ("special questions") are formally distinguished from "standard" (or information) questions by other means; see Section 7.1, below.

30. "Why-like what" is a crosslinguistically widespread phenomenon. It is found in languages as diverse as Italian, Icelandic, Czech, Hungarian, Hebrew, Japanese, Bangla and in many others. 
(43) Wie siehst du denn aus?!

how look you DENN out

'You look extremely/unacceptably strange / weird / . . '

(44) Was lachst du denn so dumm?! SDQ ("why-like what") what laugh you DENN so stupidly

'Why do you laugh so stupidly?!' ('You should not laugh so stupidly!')

In (45), echoing (3), we find the Cfv-interpretation.
Wo liegt nur / blo $\beta$ meine Brille?
where lies NUR/ BLOSS my glasses
CfvQ
'Where on earth did I put my glasses? (I have already looked everywhere)'

In (46) $(=[4])$, we find an RQ.

Wer zahlt schon gerne Steuern?
who pays SCHON gladly taxes
'Who likes paying taxes? (Nobody!)'

'Who likes paying taxes? (Nobody!)'

"Why-like what" signals a special question. Given its obligatory SDinterpretation, it is incompatible with CfvQs and RQs. The particle denn could in principle be absent. In fact, however, there is a strong tendency to use it nevertheless. The use of denn seems to support the SDQ interpretation. ${ }^{31}$ Leaving out the particle in (43), (45) and (46) preferentially leads to straight information seeking questions. It is therefore quite misleading to say that discourse particles are optional. They are in fact not. Here are some informal characterizations which build on 2.1 in order to show how the special interpretation of wh-questions might be triggered.

Denn is the most general of the particles under consideration as it establishes a strengthened relation with the linguistic context, strengthened in the sense

In an apparently uniform manner, the least marked wh-pronoun, standardly argumental, here functions as an adjunct, with an interpretation expressing a combination of surprise and disapproval on the side of the speaker. The actual meaning is hard to pin down; the closest aproximation we can give is why (the hell). Also cf. the appendix.

31. This can be seen in cases in which the contentful part of the question is neutral toward the SDQ interpretation, e.g. in (i). The SDQ-interpretation is more immediately arrived at when the particle denn appears as in (ii).

(i) Was machst du das Fenster auf? what make you the window open

(ii) Was machst du denn das Fenster auf? what make you DENN the window open 'Why do you open the window?! (you should better not do that)' 
that it overtly expresses a quasi-anaphoric relation with the actual situation. Recall that the presence of denn as such (as in [1] and [33]) does not force the special question (i.e., SDQ) interpretation of a wh-interrogative. In an information seeking question denn demands that the expected true answer $p$ update the (assumed) common knowledge of speaker and addressee in such a way that $p$ is relevant to the knowledge of the speaker. ${ }^{32}$ An SDQ may receive an answer, too but its pragmatic goal is not to obtain an answer in the narrow sense of providing a value for the variable. SDQs express the speaker's - mainly negative or critical - attitude. In some cases as in (43), if used in face-to-face communication, the answer may be obvious to the interlocutors and is thus ruled out by the Gricean maxim of relation (relevance). In this case there is an implicature by which the value of the variable gets contextually determined, e.g. in (43) as a negative value on the scale of appearances. This does not, of course, preclude an explanation or some other reaction from the addressee. The core semantics of denn essentially remains what it is in information seeking questions. Denn imports the proper contextualization and signals that the speaker is concerned - here mainly negatively or critically - about the value of the whvariable

$N u r$ and $b l o \beta$ are more special. Unsurprisingly, they function as eliminative operators as in their function as focus particles. As a focus particle with the semantic impact of only, nur|blo $\beta(\mathrm{p})$ denies the truth of proposition $\mathrm{p}, \mathrm{p}=[\ldots$ FOC ... ], with respect to alternatives of FOC. ${ }^{33}$ As a discourse particle, $n u r \mid b l o \beta$ seems to express the speaker's elimination of the values that he or she has been able to consider for the wh-variable while in principle assuming that such a value does exist. This is true even in the presence of a modal like können 'can' as in Wo kann er die Schlüssel nur|bloß gelassen haben? 'Where(ever) could he have left the keys?'34

Schon ('already') has in its core meaning a temporal interpretation. It requires a scale on which already (p) denotes a state p right after $\neg$ p. The

32. Cf. Bayer (2008).

33. dass er nur LAS ('that he only READ') is false for alternatives of the reading property, e.g. writing, listening to music, playing chess etc. but true for the reading property. Cf. Rooth (1985), Bayer (1996) among many others.

34. The particle nur - but strangely not blo $\beta$ - also occurs in imperatives with a summoning interpretation as in (i) where right may get close to nur.

(i) Komm nur rein!

come NUR in

'Come right in!'

In imperatives, $b l o \beta$ is reserved to those with an admonitory interpretation. We leave open the question whether in (i) and in the parallel exclamative with $b l o \beta$ the eliminative function can again explain the particular interpretation. 
temporal scale can be transposed to other scales, e.g. a local scale (We are already in Paris) or a prestige scale (John is already associate professor) ${ }^{35}$ Imagine that in wh-questions schon may induce a similar scale by which the entities $\left\{\mathrm{e}_{1}, \mathrm{e}_{2}, \ldots, \mathrm{e}_{\mathrm{n}}\right\}$ that can replace the variable are ranked according to their plausibility or likelihood of yielding a true answer. This creates the implicature that few entities are high enough on the scale to make the answer true, and that the upper region of the scale may in fact be empty. ${ }^{36}$

The semantics of the discourse particles under consideration explains why denn has scope over nur/blo $\beta$ or schon and why scope reversal leads to semantic ill-formedness. ${ }^{37}$ It is also easy to see why $n u r / b l o \beta$ cannot mix with schon: *Wo liegt schon nur meine Brille?, *Wo liegt nur schon meine Brille? The reason is that one particle suggests that the value of the variable has not been found while the other suggests that the value is low on some scale, i.e. there is a contradiction.

We can conclude that discourse particles make an essential semantic contribution to the interpretation of wh-questions as special questions. In the next section we will return to the syntax of discourse particles and in doing so prepare the ground for a syntactic account of special questions.

35. Cf. Löbner (1990) for a detailed semantics of schon and its correspondent noch 'still.'

36. (4)/(46) are examples of that kind, but there are others in which the implied set cannot be empty. Consider (i).

(i) Wo wird Klaus schon sein?

where will Klaus SCHON be

'Where will Klaus be? (The answer is obvious)'

Since people must be located somewhere, (i) will get an interpretation according to which the place at which Klaus is located is obvious or high on some other scale (of positive or negative evaluation). Thanks to Sebastian Löbner (p.c.) for discussion of schon as a discourse particle. As in the earlier case of nur, we leave open whether the scale effect can account for the meaning of the imperative.

(ii) Komm schon rein!

come $\quad$ SCHON in

'Come in (and do so rather quickly; don't hesitate)!'

Relevant discussion of schon on the basis of Löbner's account can be found in Meibauer (1994: Ch.6).

37. The reviewers seem to understand this as an argument against the universal structural ordering that Cinque (1999) has suggested for the adverb hierarchy. We do not see it this way. First of all, in the case of discourse particles one cannot seriously speak of universals given that their cross-linguistic recurrence is incomparably weaker than the cross-linguistic recurrence of adverbs. Secondly, we do not think that it would hurt if structural order corresponds to semantic irreversibility of scope. We would rather be surprised if it was otherwise. 


\section{Discourse particles and constituency}

Before we proceed with special questions, let us pause for a moment and return to the considerations of phrase structure that have determined the discussion so far. One of the core properties of discourse particles is that they are immobile (cf. property iv in Section 1). Unlike adverbs, they can neither be preposed nor extraposed. Immobility is an important diagnostic. If one ignores phonologically conditioned movement as in cliticization, syntactic immobility seems to be a property of functional heads..$^{38}$ Nevertheless, an important qualification must be added: various particles - in particular those under consideration - can appear as a co-constituent with wh and in this case move together with it. Consider (47) through (52), all data from the internet. ${ }^{39}$

[Wer denn] soll befehlen?

who DENN should command

'Who is then supposed to command?'

http://gutenberg.spiegel.de/?id=5\&xid=1502\&kapitel=23\&cHash=0476abe10fampfl22\# gb_found

(48) [Wer denn] soll lesen, was ich in diese Hefte who DENN should read what I in these copy-books schreibe?

write

'Who is then supposed to read what I write into these copy-books?' http://correcteurs.blog.lemonde.fr/2007/07/02/rabit/

(49) $[$ Warum bloß] ist ein Rauschenberg so teuer? why BLOSS is a Rauschenberg so expensive 'Why the hell is a Rauschenberg so expensive?'

Title of an article by Friedrich Schneider et al. from 1983 in Kunst und Wirtschaft. Bachem, Köln. 50-81.

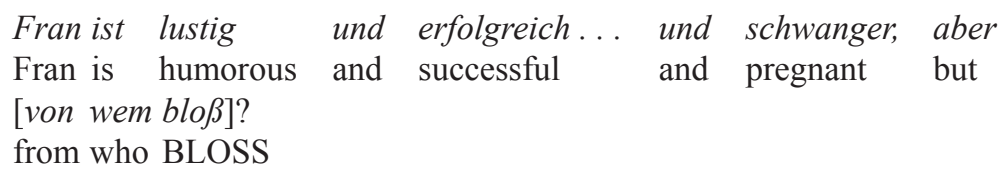

38. In the case of pre- $v \mathrm{P}$ discourse and focus particles or negation a plausible reason could be that their scope is frozen.

39. The examples are somewhat marked but appear frequently in all kinds of communications, also in written German. It is interesting to see that the wh+Prt constellation is also found in certain Northern Italian dialects. Hack (2009) provides data from Fascian Moenat but gives a different analysis. The linear order wh+Prt is also reported from Pagotto (Bellunese) in Munaro and Poletto 2004) but their examples appear to be different from ours. 
'Fran is nice and successful ... and pregnant. But by who? (I've no idea.)'

http://www.amazon.de/Romane-Babybauch-rund-Schwangerschaft-Teil//m/ F3654FYFY12F

(51) [Wo schon] wird das Weihnachtsfest inniger where SCHON becomes the Christmas more-profoundly gefeiert als in der Montanregion Erzgebirge? celebrated than in the mining-region Erzgebirge 'Where is Christmas more profoundly celebrated than in the Erzgebirge? (Nowhere!)' www.ethbib.ethz.ch/pub/agricola_15_2006.pdf

(52) [Von wem schon] kann man das sagen? of who SCHON can one that say 'Who can one say that about? (Nobody!)' http://www.zeno.org/Shop/F/0325-22497001-isbn-3608936653-schomel-wolfgangreinheit-des-augenblicks.htm

Given the basic architecture in (24) in which Prt is a head that takes VP/vP as its complement and projects a PrtP, how could these cases be accounted for? We can exclude an analysis according to which the wh-phrase moves and on its way "decapitates" the PrtP, taking its head Prt along. There is no independent motivation for such a process; in particular, there is no reason to believe that the particle attaches to the wh-phrase via a PF-operation such as cliticization. It is on the other hand known from the study of focus particles that they form constituents with XPs or various lexical categories as seen in (53).
a. They met [even John].
b. They went [even to Paris].
c. They were [even dangerous].
d. They complain [even if you feed them].

The focus particle even also allows attraction of the focus-XP to its left as seen in (54).
a. [John even] complained.
b. [John even John] complained.

In German, focus particles can attract the focus XP even more productively. Here are some examples with nur.

Alle anderen gingen in Begleitung und [sie nur $]$ sollte
all others went in company and she only should
allein gehen wie ein Hund ohne Herrn?
alone go like a dog without master


'All the others went in company, and only she should go alone like a stray dog?'

http://ngiyaw-ebooks.org/ngiyaw/zapolska/kaethe/kaethe.htm

(56) [Heute nur] ist das noch möglich. today only is this still possible

'Only today is this still possible.'

http://www.archive.org/stream/3569904/3569904_djvu.txt

(57) [Einer nur] hat es geschafft, seine Copy- Twice-Strafarbeit one only has it achieved his copy twice imposition zu halbieren.

to divide

'Only one (of them) has managed to cut his copy twice imposition in half.'

www.du.nw.schule.de/merc-gym/Downloads/Festschrift/erinnern.pdf

A straightforward analysis is that the focus particle is a head that is merged with a focal XP which can be raised to the left of the particle due to a requirement of additional feature checking. This analysis is in line with the V2constraint because particle and XP form a single constituent. ${ }^{40}$ We assume that analogously, in the case of the discourse particles in (47) through (52) the head Prt is merged with the wh-phrase. The latter, which bears extra heavy stress, will be raised to the left of Prt. Thus, [wh [Prt wh]] is a constituent, and again there is no conflict with the V2-constraint. Comparing adverbs with discourse particles, we note that the two behave differently. Adverbs such as gewöhnlich 'usually,' normalerweise 'normally' can hardly be merged with wh-phrases. ${ }^{41}$

40. This is not the case in Jacobs (1983) and Büring and Hartmann (2001) who insist that the particle is "adverbial" and does not form a constituent with the focal XP. These authors must assume that German is a V3-language, and that it has this exceptional property just in these cases. We would like to avoid this highly unattractive consequence. As we are showing here, this can be done in a very natural way.

41. Consider the examples in (i) and (ii). If discourse particles were simply adverbs, we would expect (ib) and (iib) to be grammatical.

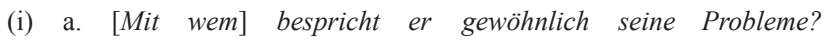
with who discusses he usually his problems

'Who does he usually discuss his problems with?'

b. *[Mit wem gewöhnlich $]$ bespricht er seine Probleme?

(ii) a. [Wen $]$ hat er normalerweise getroffen? whom has he normally met

'Who did he normally meet?'

b. *[Wen normalerweise $]$ hat er getroffen? 
This contrast constitutes additional support for theories which attribute head status to discourse particles.

As for the leftward movement of the wh-phrase around the discourse particle, we suggest that it is triggered by a feature of emphasis inherent in the particle. There is independent evidence that emphasis is a concept in syntax, and that it is in all likelihood a root phenomenon (cf. Behaghel [1932: vol IV]). For the cases at hand, we observe that the emphatically marked phrases usually appear in the highest position as seen in (47) through (52). Notice the contrast between (58a) and (58b).
a. Wer hat (denn) damals (denn) [wem] geholfen? who has DENN then DENN whom helped 'Who helped whom in those days (I am wondering)'
b. ?*Wer hat damals [wem denn] geholfen?

If this contrast is real, then it could show that an emphatically marked XP must access the clausal left periphery, and that this is due to the presence of a root-sensitive feature of emphasis inherent in [wh Prt] which requires preposing. ${ }^{42} 43$

Let us suggest then that next to the "regular" derivation in which Prt is merged with $\mathrm{VP} / v \mathrm{P}$ and thus has fixed scope, there is an alternative derivation in which Prt is merged with a wh-phrase, under the condition that the latter has an extra feature of emphasis which values an uninterpretable counterpart on

42. As has been shown in Bayer (2001), emphatically focused (non-wh) XPs move to SpecCP in Bavarian, giving rise to the order $\left[{ }_{\mathrm{CP}} \mathrm{XP}_{\mathrm{emp}}\left[\mathrm{C} \mathrm{C}\left[\mathrm{TP} \ldots \mathrm{XP}_{\mathrm{emp}} \ldots\right]\right]\right]$; the entire $\mathrm{CP}$ is then forced to move to the specifier of the root clause. The reason for this is that by virtue of Emppreposing, $\mathrm{CP}$ is +emphatic, and that this feature can only be interpreted when the $\mathrm{CP}$ is in the specifier of the root's Force/Fin projection. The case is comparable with hanging topic constructions. If a hanging topic is attached to a dependent $\mathrm{CP}$, this $\mathrm{CP}$ as a whole must undergo leftward movement.

(i) *I find rather surprising [John \# that you don't know him].

(ii) [John \# that you don't know him $]_{1}$, I find rather surprising $\mathrm{t}_{1}$.

43. A counterexample to preposing could be a famous passage from the $3^{\text {rd }}$ act of Wagner's "Parsifal" in which Parsifal sings:

(i) Nur eine Waffe taugt. Die Wunde schliesst der Speer nur, only one weapon suffices the wound ${ }_{\mathrm{ACC}}$ closes the spear $_{\mathrm{NOM}}$ only

der sie schlug.

that it caused

'Only one weapon will suffice. Only the spear that caused the wound will ultimately heal it'

Here the critical DP der Speer nur is in the middle field. But notice that this is a highly poetic register. 
Prt. This amounts to saying that next to the formation of a "big PrtP" as in (24) and subsequent representations, German syntax also allows the formation of a "small PrtP". Notice that in this case the order Prt+wh is ungrammatical. The wh-phrase raises obligatorily to the left of Prt. ${ }^{44}$ Before we turn to consequences of this option, let us see how the derivation of a small Prt could proceed. The relevant feature being "emphasis", an unvalued feature uEmp on the particle attracts an emphatically focused wh for valuation. We assume that the wh-phrase bears emphatic stress and is endowed with the interpretable and unvalued feature $i \mathrm{Emp}$ [ ], and that the discourse Prt which is merged with a wh-phrase has an EPP-feature. The EPP-feature, which we suppress in the following formalizations for reasons of readability, requires overt movement of the wh-phrase.

(59) $\operatorname{Prt}^{\circ}{ }_{\text {EPP, } u \text { Emp [ ] }}$ wh $_{i \text { Emp [ ] }} \quad==$ AGREE, EPP $==>$

(60) $\quad\left[w_{i \text { Emp [7] }}\left[\operatorname{Prt}^{\circ}{ }_{u \text { Emp [7] }}\right.\right.$ wh $\left.\left._{i \text { Emp [7] }}\right]\right]$

"Small PrtP"

The resulting small PrtP such as [warum blo $\beta]$ has a feature for emphasis but in addition also the Q-feature. Thus, the small PrtP is + prt, +Q, +emp. As an alternative to the EPP, the +emp property as such might be responsible for the obligatoriness of overt wh-raising and ultimately also resistance against wh-insitu as suggested by (58b).

Notice next that particles can be stacked in small PrtPs, in which case the particles retain exactly the same order as in their pre- $\mathrm{VP} / v \mathrm{P}$ occurrences. Examples from internet sources are given in (61) through (63).

[Warum denn nur] kann AMD ihre CPUs billiger
why DENN NUR can AMD its CPUs cheaper
anbieten als Intel???
offer than Intel
'Why on earth can AMD offer their CPUs cheaper than Intel (I am
wondering)?'
http://3dfusion.de/forum/archive/index.php/t-1152.html

[Wie denn bloß] kann ich sie fangen?

how DENN BLOSS can I her catch

'How on earth can I catch her (I am wondering)?'

http://www.e-stories.de/gedichte-lesen.phtml?70420

44. Here, the discourse particles are at variance with focus particles. Focus particles merge with a focused XP, which leads to the order Prt $+\mathrm{XP}$, but they also allow, as a marked option, raising of XP (cf. (54)-(57) and (i) in note 43). If a discourse particles merges with a wh-XP, this whXP must raise: had wer failed to raise in, say, (47), the example in (i) would be out.

(i) *[Denn wer $]$ soll befehlen?

DENN who should command 
(63)

[Wer denn schon] würde es der Meinung eines Dritten
who DENN SCHON would it the opinion ${ }_{\mathrm{DAT}}$ a third GEN
verbieten wollen die deine $z u$ meiner zu machen?
prohibit want the your to mine to make
'Who would deny the opinion of a third person to make your opinion
míne?'
http://www.esoterikforum.de/magie/5323-kampfmagie-9.html

We propose that the emphatically marked wh-phrase can value the Empfeatures on Prt recursively as shown in the derivation in (64), the result being a "Recursive Small PrtP".
a. $\operatorname{Prt}^{\circ}{ }_{u \text { Emp [ ] }}$ Wh $_{i \text { Emp [ ] }}$
b. $\left[\right.$ Wh $_{i \operatorname{Emp~[7]~}}\left[\operatorname{Prt1}^{\circ}{ }_{u \text { Emp [7] }} \mathrm{Wh}_{i \operatorname{Emp~[7]~}]]}\right.$
$\Rightarrow$ Move wh
c. $\operatorname{Prt}^{\circ}{ }_{u \text { Emp [ ] }}\left[\mathrm{wh}_{i \operatorname{Emp~[7]~}}\left[\operatorname{Prt}^{\circ}{ }_{u \text { Emp [7] }}\right.\right.$ wh $_{i \text { Emp [7] }]]} \Rightarrow$ Move wh
d. $\quad\left[\mathrm{wh}_{i \operatorname{Emp~[7]~}}\left[\operatorname{Prt}^{\circ}{ }_{u \text { Emp [7] }}\left[\mathrm{Wh}_{i \operatorname{Emp~[7]~}}\left[\operatorname{Prt}^{\circ}{ }_{u \text { Emp [7] }} \mathrm{wh}_{i \operatorname{Emp~[7]}]]]}\right.\right.\right.\right.$ "Recursive Small PrtP"

A small PrtP must be related to the "big PrtP" structure we have established in (24). Relatedness is not only suggested by the fact that small PrtP and big PrtP show the same ordering restrictions in examples of stacking but also by the fact that Prt needs to take scope. According to (24), its scope is the verbal projection. We have now argued that the small PrtP is derived separately and is then merged into the developing phrase marker by a generalized transformation. If the small PrtP is an argument it will occupy a position in $\mathrm{VP} / \nu \mathrm{P}$. The syntactic category of the small PrtP is whatever the XP-complement of Prt is: a DP, a PP, an AdvP etc. From this perspective, the small PrtP will be merged according to standard procedures. Beyond its categorial status, however, the small PrtP is, also marked for + prt, $+\mathrm{Q}$, +emp. These features must be satisfied. By virtue of + prt, the XP must move to a position where the particle can have scope (and associate with ForceP); by virtue of $+\mathrm{Q}$, it must move to a $\mathrm{Q}-($ wh-)position; and by virtue of +emp, it must presumably move to a position of the root clause in which the speaker's gesture of emphasis can be interpreted. Given that we have already established the existence of big PrtP, the first step of the small PrtP must be to target a matching big Prt-position and subsequently a matching Q-(wh-)position, and ultimately a matching root position at which +emp will be interpreted. Given the clausal architecture so far, the derivation is entirely as expected. The small PrtP's structural shells map onto the hierarchy of functional heads which have been identified in clause structure. Thus, there is featuredriven movement from the $\mathrm{VP} / \nu \mathrm{P}$-internal base position via the left edge of $\mathrm{VP} / v \mathrm{P}$ to SpecPrtP to SpecCP (in non-root clauses) and finally to SpecForceP/ SpecFinP. Assume that a silent Prt, the head of the big PrtP, has been merged to 
$\mathrm{VP} / v \mathrm{P} .{ }^{45}$ Using the feature system which is familiar by now, the small PrtP, as before, has an uninterpretable and unvalued feature $u \operatorname{Prt}[$ ] which moves to the specifier of the silent Prt, the head of the big PrtP. This head is $i$ Prt and will be valued when a matching small PrtP moves to SpecPrtP. Since the small PrtP is simultaneously a wh-XP, it will have to move on to SpecCP or to SpecFinP/ SpecForceP. Since the small PrtP is also $i$ Emp [ ], it will ultimately have to move to SpecForceP (if this is the right place for the interpretation of emphasis). (65) provides the derivation in formal detail. As argued in detail in Section 2.5.2, Prt also bears the feature uQForce [ ]. We omit this feature here for the sake of readability.

$$
\begin{aligned}
& \text { a. } \quad\left[\mathrm{vP} / v \mathrm{P} \ldots\left[\mathrm{PrtP} / \mathrm{whP}_{u \operatorname{Prt}[}\right] ; u \mathrm{Q}[\mathrm{]}] \ldots\right] \\
& \Rightarrow \text { Merge a silent Prt } \\
& \text { b. } \quad\left[\operatorname { P r t P } \operatorname { P r t } ^ { \circ } { } _ { i \operatorname { P r t } } [ ] \left[\mathrm{VP} / v \mathrm{vP} \ldots\left[\operatorname{PrtP} / \mathrm{whP}_{u \operatorname{Prt}[] ; u \mathrm{Q}[\mathrm{]}] \ldots]]}\right]\right.\right. \\
& \Rightarrow \text { Move small PrtP }
\end{aligned}
$$

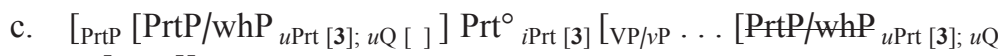

$$
\begin{aligned}
& \text { [ ] ]...]] } \\
& \Rightarrow \text { Merge Force/Fin }
\end{aligned}
$$

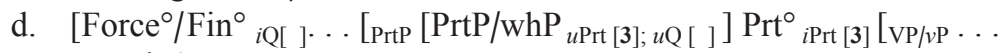

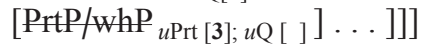

$$
\begin{aligned}
& \Rightarrow \text { Move whP } \\
& \text { e. } \quad\left[\left[\operatorname{PrtP}\left[\operatorname{PrtP} / \mathrm{whP}_{u \mathrm{Prt}[3] ; u \mathrm{Q}[9]}\right] \text { Force }^{\circ} / \mathrm{Fin}^{\circ}{ }_{i \mathrm{Q}[9]} \ldots \mathrm{PPrP}\left[\mathrm{PrtP} / \mathrm{whP}_{u \mathrm{Prt}}\right.\right.\right. \\
& [3] ; u \mathrm{Q}[9]] \operatorname{Prt}^{\circ}{ }_{i \operatorname{Prt}[3]}\left[\mathrm{vP} / v \mathrm{P} \ldots .\left[\operatorname{PrtP} / \mathrm{whP}_{u \operatorname{Prt}[3] ; u \mathrm{Q}[9]} \ldots\right. \text { ] ] ]] }\right.
\end{aligned}
$$

In (65c) the small PrtP has been moved to a scope position for Prt. We assume that its scope freezes in this position. The head Prt of the big PrtP has been identified via agreement at this stage of the derivation, and the restrictive part of the wh-phrase in small PrtP is stripped off and relegated to the $\mathrm{VP} / v \mathrm{P}$ internal position which contains a copy. The work of Prt-licensing has been completed at this stage. But there are more features to take care of. After Force/Fin has been merged in (65d), the small PrtP moves on because it has to discharge a Q-feature (and an emp-feature which is not represented here for reasons of readability). If Force/Fin is endowed with an interpretable Qfeature, the small PrtP will move to its specifier. Why should this phrase move on? It must move at this stage of the derivation for the sole reason that it has an uninterpretable and unvalued Q-feature, $u \mathrm{Q}$ [ ]. Prt is pied-piped along. It has no function in the landing site where we see it in (65e). The logic of the derivation extends naturally to the feature of emphasis. We skip a demonstration for

45. To be sure, there may be more parsimonious and more elegant alternatives. Adjunction of the small PrtP to VP/vP may trigger the emergence of a scopal Prt-head. We ignore such technical alternatives here and try to stay as conservative as possible. 
the sake of keeping the discussion as focused as possible. We will likewise leave aside a detailed demonstration of derivations in which a more complex small PrtP participates. As we have argued above, the actual structure of the creature in (66a) would be as in (66b).
a. warum denn nur why DENN NUR
b. [warum [denn [warum [nur warum] $]]]$

Speaking in informal terms, this small PrtP will first target a lower big PrtP, related to nur, then the next big PrtP, related to denn, and finally CP or FinP/ ForcP.

To summarize at this point, we have shown that the small PrtP has properties which go beyond those of the big PrtP: Prt is merged with a wh-XP which is raised to SpecPrtP for reasons of emphasis. Both wh and emphasis must be licensed outside the big PrtP. The fact that Prt will be taken along by whmovement should not be seen as connected to the scope of Prt. According to our analysis, the movement to SpecCP or SpecFinP/SpecForceP has nothing to do with the scope of Prt. It is a mere reflex of pied-piping. The small PrtP moves for reasons of categorial integrity not for semantic reasons. Contrary to certain claims, the "unusual" constituency of the small PrtP does not cause any semantic problems. The reason is that the pied-piped Prt does not take scope where it appears at PF but rather much lower. A model of syntax which respects only the PF-oriented side of the grammar has a hard time to cope with this fact. A more abstract derivational model, on the other hand, has no problems because a single XP can be recycled through different layers of structure as often as needed until all its features have been valued.

\section{Mixed constituency}

So far we have seen the standard case ("big PrtP") in which Prt ${ }^{\circ}$ is merged with $\mathrm{VP} / v \mathrm{P}$, and the more marked case ("small PrtP") in which Prt has an Empfeature and is merged with an emphatically accented wh-phrase. The resulting small PrtP moves in two steps. By the first step, Prt attains scope over VP/vP, by the second step the wh-phrase inside the small PrtP attains scope over CP or FinP/ForceP. Given the rich possibilities of stacking question-sensitive discourse particles that have been demonstrated so far, it is naturally expected that the two phrase structural possibilities can be combined: While one Prt is merged with $\mathrm{VP} / v \mathrm{P}$, another one may be merged with a wh-phrase thus creating what we have called a small PrtP. The data verify this expectation. 
(67)

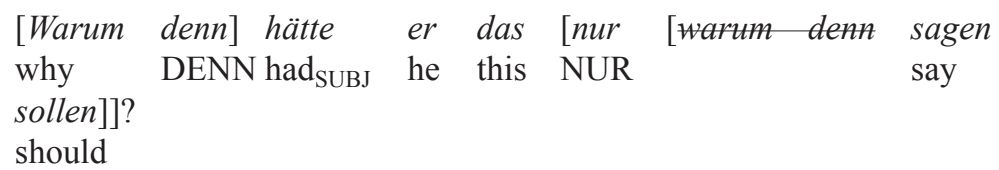

'Why on earth should he have said that (I am wondering)?'

(68) [Warum denn] glaubst du [warum denn dass er [nur warum denn why DENN believe you that he NUR

so gehässig ist]]]?

so malicious is

'Why on earth do you believe that he is so malicious (I am wondering)?'

In fact, (68) should be ambiguous depending in which CP-cycle the small denn $\mathrm{P}$ (warum denn) activates its scope. It can do so in the embedded clause or in the root clause. The first has a correspondent in the unambiguous example (69), the second in the unambiguous example (70).

(69) Warum glaubst du [warum dass er [denn [nur warum so gehässig ist]]]?

(70) Warum glaubst du [denn [warum dass er [nur warum so gehässig ist]]]?

Given that the small PrtP moves to SpecCP only for the reason of wh-checking and not at all for the reason of providing extra scope for Prt, we expect that the small PrtP is interpreted in a reconstruction position qua its lexical contribution. As (69) and (70) show, denn is licit in either of the two positions. According to the present theory, the small PrtP warum denn could have activated a big denn $\mathrm{P}$ in the embedded clause or in the root clause. In each case, however, the reconstruction site must be above the scope of nur. Recall that the order nur $<$ denn is ungrammatical.

If the discourse particle of the small PrtP takes scope in a reconstruction position, another prediction is made, namely that in a case of mixed constituency the linear order of the particles may be reversed. Although the order nur < denn is ungrammatical, this linear order should be observed in cases in which nur is part of a small PrtP which has taken scope below denn before moving on for wh-checking. This prediction is borne out. (71) is fully grammatical although it shows the linear order nur $<$ denn.

$$
\begin{aligned}
& \text { [Warum nur] hätte er das [denn sagen sollen]]? } \\
& \text { why NUR had } \text { SUBJ }_{\text {Se this }} \text { DENN say should } \\
& \text { 'Why on earth should he have said that (I am wondering)?' }
\end{aligned}
$$

As the representation in (72) shows, the linear order is irrelevant. What is relevant is the relative scope of the two particles.

(72) [Warum nur] hätte er das $\left[\mathrm{PrtP}_{1}\right.$ denn $\left[\mathrm{PrtP2}\right.$ warum nur ${ }_{\mathrm{v} \mathrm{p}}$ warum nur sagen sollen]]]? 
In (72), the small PrtP warum nur has been moved to the specifier of PrtP2. The head of PrtP1, denn, is merged with the output of this operation. Thus, denn takes scope over nur as required. The fact that the small PrtP moves on creating a "deviant" linear order is a matter of PF which is irrelevant for the calculation of scope.

An important message can be derived from the examples in (67) through (72) and their analysis within the present theory: First, the discourse particle itself executes its scope as the head of a big PrtP as initially suggested in (24). Secondly, the force feature inherent in Prt, here [QForce], must be divorced from the particle's lexical contribution. As has been argued in Section 2.5.2 above, it is the force feature which associates with the licensing Force/Fin head while the particle as such remains in its underlying scope position. This precludes analyses by which the particle itself moves to ForceP. The other important message is that the surface appearance of the small PrtP should not be mistaken as the particle's scope position. The fact that the Prt of a small PrtP takes scope in a lower position may shed new light on the debate about focus particles. Büring and Hartmann (2001) want to show that the particle that initiates a V2-sentence as in (73) takes scope right where it occurs at PF because nur takes scope over negation.

\section{(73) Nur FLEISCH hat niemand gegessen. only meat has nobody eaten 'Only for meat it is true that nobody ate any.'}

From this, the authors conclude that nur cannot be a constituent of a phrase nur FLEISCH and must therefore be an adverbial XP that precedes the V2 clause. To the extent that the syntax of discourse particles has any bearing on this debate, the findings reported in Section 5 refute their analysis. ${ }^{46}$

46. As a matter of fact, the example in (73) is ambiguous. The scope of nur can well be smaller than the scope of negation as long as niemand is accented.

(i) Nur FLEISCH hat NIEMAND gegessen.

only meat has nobody eaten

'It is not the case that someone ate nothing but meat.'

We take this as evidence that (i) is structurally ambiguous between the representations in (ii) and (iii).

(ii) Nur FLEISCH hat nur FLEISCH niemand nur FLEISCH gegessen.

(iii) Nur FLEISCH hat niemand nur FLEISCH gegessen.

In (ii), nur takes scope in a scrambling position above the $\mathrm{NegP}$ which contains niemand in its specifier. In (iii), nur takes scope in the $\nu \mathrm{P}$ below NegP. If we are right, the appearance of nur in the derived position of SpecFinP has no scopal relevance at all. 
In Section 6, it will be shown that small PrtPs interact with special questions in an interesting way, and that this interaction appears to be of cross-linguistic relevance for an understanding of special questions in languages other than German.

\section{Small PrtP in special questions}

As has been made clear in Section 3, discourse particles play an important role in the fine-tuning of questions. They yield "Surprise-Disapproval Questions" (SDQs), "Can't-Find-the-Value Questions" (CfvQs), rhetorical questions (RQs), and perhaps additional types. Considering now small PrtPs, we see that the combination of a wh-phrase with nur allows the CfvQ interpretation, while the combination of a wh-phrase with schon allows the RQ interpretation.

$\left.\begin{array}{ll}\text { Wo } & \text { nur }\end{array}\right]$ ist der Stolz geblieben? CfvQ where NUR is the pride remained

'Where on earth did the pride remain?'

http://debatte.welt.de/kommentare/90018/wo+nur+ist+der+stolz+geblieben

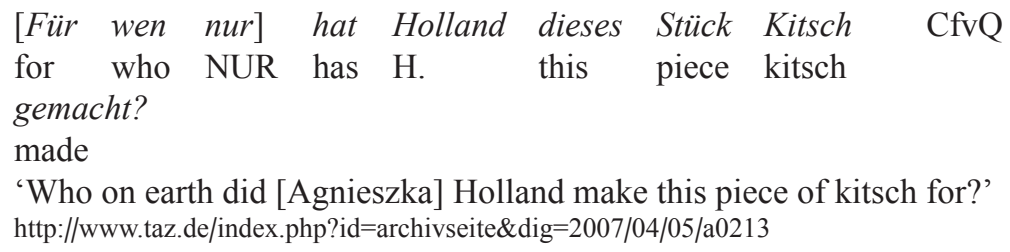

(76) [Wen schon] kann man nachts um drei nach dem Weg RQ who SCHON can one at-night at three for the way fragen?

ask

'Who can you ask directions at 3 o'clock in the night? (Nobody!)' www.onlinechronik.de/aktuell/chron_april_2001.htm

(77) [Wann schon] hat man zuletzt deutsche Sportler so when SCHON has one last German sportsmen so selbstbewußt aufspielen sehen? self-confidently play seen

'When have German sportsmen last been seen playing with such self-confidence? (Never!)'

www.spiegel.de/sport/fussball/0,1518,269742,00.html

In (74) through (77), the particle could equally well appear in pre-VP/ $/ v$ position, as noted before. The interpretive difference is that CfvQs and RQs with a small PrtP have an extra touch of emphasis. Interestingly, however, the 
small-PrtP construction is incompatible with the SDQ-interpretation. The contrast between a. and b in (78) and (79) is sharp.
a. Wie siehst du denn aus?! (=43) how look you DENN out 'You look strange / weird / . .'
b. *[Wie denn] siehst du aus?!

a. Was lachst du denn so dumm?! (=44) SDQ what laugh you DENN so stupidly 'Why do you laugh so stupidly?!'

b. *[Was denn] lachst du so dumm?!

Let us turn first to "why-like" what in (79b). As d'Avis (1996) and Munaro and Obenauer (1999) have pointed out, "why-like" what, as seen in (44) / (79a), does not behave like a normal wh-operator in various ways ${ }^{47}$ All the evidence suggests that the was of (79a) is obligatorily unfocused; thus, among other things, it is not available in situ, e.g. in multiple questions, as shown by the contrast in (80).

(80) Wer hat denn \{warum/*was\} so blöd gelacht? who has DENN why what so stupidly laughed 'Who laughed why so stupidly?'

Unmoved wh, i.e. "wh-in-situ", can only occur in focus position. Given that the small PrtP is built on the basis of checking a feature for emphasis, i.e. a property which presupposes focus, it follows that "why-like" what is incompatible with the occurrence in a small PrtP.

This type of account does not extend to the case of (78b): wie 'how' is not intrinsically restricted in the way "why-like" what is (nor, in fact, are the other wh-elements). Wie is compatible with focus; it can, for example, stay in situ, as in (81).
Wer hat denn wie ausgesehen?
who has DENN how looked
'Who looked like what?'

(81) elicits the familiar pair-list answer. Thus, it is not too surprising to see that wie can also enter the small denn-PrtP as seen in (82).

[Wie denn] ist es zu erklären, dass Mathematik zumindest in how DENN is it to explain that mathematics at-least in NRW das häufigste (..) Abiturfach ist? NRW the most-frequent Abitur-subject is

47. Cf. the appendix. 
'How can it be explained that mathematics is at least in NRW the mostly chosen subject for the school final exam?'

http://www.stauff.de/matgesch/dateien/unbeliebt.htm

(82) is an information question albeit one with the note of emphasis which may give rise to certain implicatures. It is certainly not an SDQ. For our present purposes, this suffices to demonstrate that the "why-like" what SDQ is not an isolated case, and that other wh-pronouns can occur in SDQs as well. This allows the conclusion that SDQ is an illocutionary type which is systematically connected with a certain syntactic form. The contrast between the well-formed question in (82) and the ill-formed SDQ in (78b) seems to systematically correlate with an interpretive contrast. SDQs are, beyond the individual case of "why-like" what, distinguishable by their incompatibility with a small dennP, thus contrasting with standard information-seeking questions as well as with CfvQs and RQs.

\section{Some cross-linguistic evidence for SDQs}

The consequences of the observations about special questions and in particular of SDQs are at this moment not completely clear. Does German employ different landing sites for focal and for non-focal wh-phrases, with SDQs resorting to the latter? Due to its uniform V2 organization, German may not reveal existing differences in terms of landing sites. ${ }^{48}$ However, a number of Italian dialects display distinct syntactic strategies across question types. Most tellingly, Bellunese, a dialect of the Veneto spoken around Belluno, shows that in SDQs the wh-phrase moves to a higher position than in standard information-seeking questions. Another relevant example seems to be the Indo-Aryan language Bangla (also known as "Bengali"), spoken in the Indian state of West-Bengal and in Bangladesh. We will briefly turn to examples from these two languages in 7.1 and 7.2 respectively.

\subsection{Bellunese}

Bellunese has (at least) the following two forms of wh-questions.

48. Frey (2004) argues for a weakly split CP in German which involves a distinction between a Fin-head with a pure EPP-feature that attracts unfocused material and a Kontr-head - the head of a "contrastive phrase" - with an EPP-feature which is associated with a feature for contrastivity. 
(83)

$A$ '-tu invidà chi?
have-you invited who
'Who have you invited?'

Chi à-tu invidà?!

who have-you invited

'Who (the hell) have you invited?! (You should not have invited him!)'

The example in which chi appears in final position is a regular informationseeking question whereas the one in which chi has moved to the left edge of the clause is an SDQ. On the basis of detailed comparative work on typologically different dialects, Poletto and Pollock (2004) argue that examples of type (83) involve a sentence-initial silent wh-clitic which agrees with the sentence internal "strong form", here the pronounced $c h i$, the latter occupying a low position in the left periphery. ${ }^{49}$ According to these authors, (83) corresponds to the (considerably simplified) structure in (85).

$$
\text { [WhCl Ø] à-tu invidà chi? } \quad(=83)
$$

Obenauer (2006) develops an analysis of special questions in Bellunese which integrates Poletto and Pollock's insights concerning standard questions. The movement of the pronounced wh to clause-initial position in (84) leads to the (simplified, again) structure given in (86), the SDQ counterpart of (85). ${ }^{50}$

$$
\text { chi }[\mathrm{WhCl} \varnothing] \text { à-tu invidà chi? } \quad(=84)
$$

SDQs, then, differ in a striking way from standard questions in Bellunese. The data again raise the question whether an analogous distinction in terms of landing sites exists between standard questions and SDQs in German, a distinction which may be less visible due to the V2-requirement. We leave this question to future research.

\subsection{Bangla}

Another language in which SDQs are formally distinguished from informationseeking questions is Bangla. The following data are taken from Bayer (1996: Ch.7). The example in (87) shows a standard question. Bangla being a "wh-in-

49. Parametric choice of the \pm pronounced element (the clitic or the strong form) distinguishes between dialects like Bellunese with a silent clitic, others with a silent strong form (but a pronounced clitic) and a third type where both clitic and strong form are pronounced.

50. Obenauer (2006) argues that the landing site of chi is the Spec of a higher, dedicated functional projection, and that CfvQs and RQs - which also move their strong forms to initial position in Bellunese - resort to different projections, all higher than the projection containing the clitic. 
situ" language, the wh-operator - actually a $k$-word like $k i$-appears in a focus position to the immediate left of the verb. ${ }^{51}$

$$
\begin{aligned}
& \text { tumi kolkata-Y ki kor-ch-o? } \\
& \text { you Kolkata-LOC what do-PROG-2 } \\
& \text { 'What are you doing in Kolkata?' }
\end{aligned}
$$

Bangla shows great word order freedom. It can in particular place arguments of the verb in postverbal position, including NPs and pronouns. Wh-operators can be found in post-verbal position only to a limited extent. In (88), the whoperator is D-linked. ${ }^{52}$

$$
\begin{aligned}
& \text { ami toma-ke de-b-o kon boi-Ta? } \\
& \text { I you-DAT give-FUT-1 which book-CL } \\
& \text { 'Which (one of the) book(s) should I give you?' }
\end{aligned}
$$

Notice now that although $k i$ (like other $k$-words) is not D-linked but can still occur in post-verbal position. However, if it does, it gives rise to an SDQ interpretation.

$$
\begin{aligned}
& \text { tumi kolkata-Y kor-ch-o ki? } \\
& \text { you Kolkata-LOC do-PROG-2 what } \\
& \text { 'What }\{\text { on earth / the hell }\} \text { are you doing in Calcutta?' }
\end{aligned}
$$

SDQ

In (89), $k i$ is unfocused. In fact, it is like a clitic that integrates phonologically in the prosodic phrase determined by the verb (here /korcho/).

Bangla has a large number of discourse particles, one of which is the cliticlike element $-\mathrm{Ta}$. This element must follow the finite verb and is used in constituent questions. ${ }^{53}$ Suffixation of $-\mathrm{Ta}$ blocks the regular interrogative interpretation in favor of the SDQ-interpretation. Once - Ta is suffixed to the verb, the $k$-word must be in post-verbal position. This is shown in the following minimal pair.

$$
\begin{aligned}
& \text { tumi kolkata-Y kor-ch-o-Ta ki? } \\
& \text { you Kolkta-LOC do-PROG-2-Ta what } \\
& \text { 'What the hell are you doing in Kolkata?' }
\end{aligned}
$$

51. According to various researchers, the focus position is a derived position into which the $k$-word has been moved. Thus, movement to SpecFocP may be something similar to whmovement. Cf. Jayaseelan (2001) for Malayalam, Simpson and Bhattacharya (2003) and Bayer (2005) for Bangla. The actual analysis does not matter in the present context.

52. CL stands for a classifier. For the concept of "D-linking" cf. Pesetsky (1987). Thanks to Probal Dasgupta and Sibansu Mukhopadhyay (p.c.) for discussion of the Bangla data.

53. The discourse particle $-\mathrm{Ta}$ must be distinguished from the homophonous classifier - Ta that appears in example (88) in the text. For relevant discussion of the role of discourse particles in Bangla cf. Dasgupta (1980; 1984: 1987). 
(91)

*tumi kolkata-Y ki kor-ch-o-Ta?

The presence of the discourse particle -Ta requires an SDQ illocutionary type of constituent questions, and as a consequence the wh-phrase ( $k$-word) is forced to stay in a post-verbal anti-focus position.

The syntactic difference between standard questions and SDQs in Bellunese and in Bangla is striking. In both languages, the SDQ interpretation is correlated with the wh-operator fleeing from a focus position. Although in German there is no comparably dramatic difference in the order of constituents, the data that "why-like" what and the small PrtP construction have brought to light in Section 6 seem to be strongly supported by the findings from Bellunese and Bangla. We can be confident that the focus avoidance of wh in SDQs is not an accident. Whatever further research may bring to light concerning the different types of questions, the findings so far point to a degree of syntactization of question types that deserves more detailed research.

\section{Conclusion}

Discourse particles are an important source of information about the relation between clause structure, its functional organization and semantic/pragmatic interpretation. Information has been provided about the form and function of German particles in wh-questions. A proposal was made as to how particles contribute to the determination of illocutionary force via diverse phrase structural configurations ("big PrtP", "small PrtP"). We have argued for a clausal architecture in which at least the discourse particles under closer consideration, denn, nur, blo $\beta$ and schon, are functional heads which, in their pre- $\mathrm{VP} / v \mathrm{P}$ occurrence, determine the scope domain. Discourse particles are an essential part of the utterance and as such must be connected to the force domain of the clause. According to the present proposal, this is achieved by a probe/goal agreement relation through which the force feature of the particle becomes interpretable in the force layer of the clause. Access to the force layer is achieved as a side effect of wh-movement, including cyclic wh-movement. In this case, the discourse particle can be at an arbitrary linear distance from its interrogative-force licenser in the force layer of the root clause. If we are right in our analysis, this finding amounts to an independent and so-far unknown diagnostic of cyclic wh-movement.

It could in addition be shown that the discourse particles under consideration can alternatively be merged with emphatically focused wh-phrases, with which they then undergo wh-movement. Various reconstruction effects show that the "small PrtP" thus formed must move through the regular pre-VP/vP PrtP (the "big PrtP") before it moves on to the checking destination of the wh-phrase. 
This finding amounts to evidence for additional cyclic movement through positions which are disctinct from SpecCP.

Discourse particles play a substantial role in the shaping of special questions, i.e. questions with a special semantic/pragmatic impact. Formation of a small PrtP requires emphatic focus on the wh-phrase. It was shown that this formation causes the construction to be incompatible with the "surprise-disapproval" interpretation of a wh-question. Comparative research from Northern Italian and Indo-Aryan languages suggests that this finding is more than an accidental cooccurrence of facts.

Some of the aspects we have treated probably deserve closer scrutiny. Nevertheless, we believe that the present research provides a new starting point for further explorations of the interplay of the different factors that contribute to establishing full interpretation of utterance types.

\section{University of Konstanz \& UMR 7023 SFL, CNRS / Univ. Paris 8 josef.bayer@uni-konstanz.de obenauer.hans@wanadoo.fr}

\section{Appendix}

\section{Why-like What}

Data in (i)-(iv) from Munaro \& Obenauer (1999).

(i) Coordination

a. Wann und warum hast du mit Max gesprochen?

'When and why did you talk to Max?'

b. *Was und seit wann schreit der denn so?

'Why and since when does he shout like this?'

(ii) Contrastive focus

a. Ich habe nicht gesagt: WANN hast du mit ihm gesprochen, sondern: WARUM hast du mit ihm gesprochen.

'I did not say, WHEN did you talk to him, but: WHY did you talk to him.'

b. *Ich habe nicht gesagt: Seit WANN schreit der denn so, sondern: WAS schreit der denn so.

'I did not say, since WHEN has he been shouting like this, but: WHY has he been shouting like this.'

(iii) Constituent answers

a. Sie schreiben also? Was?

'You are a writer, then? What do you write?' 


\section{b. Jetzt lachst du wieder so blöd. Warum (denn) / *Was (denn)? 'Now you are again laughing so stupidly. Why?'}

(iv) Wh-in-situ

Wer hat denn warum / *was so blöd gelacht?

'Who laughed why so stupidly?'

There is evidence that long (trans-CP) movement requires a phrase which is contrastive with respect to a set of alternatives. Again, warum succeeds but why-like was does not.

(v) Long-wh-extraction

Warum / *was denkst du, dass er warum / was so blöd gelacht hat?

'Why do you think that he laughed so stupidly?'

\section{References}

Abraham, Werner. 1991. The grammaticization of the German modal particles. In Elizabeth Closs Traugott \& Bernd Heine (eds.), Approaches to Grammaticalization, vol. 2, 331-380. Amsterdam: Benjamins.

Abraham, Werner. 2000. Modal particles in German: word classification and legacy beyond grammaticalization. In Petra M. Vogel \& Bernard Comrie (eds.), Approaches to the Typology of Word Classes, 321-350. Berlin: Mouton de Gruyter.

Anderson, Stephen R. 1993. Wackernagel's revenge: clitics, morphology, and the syntax of second position. Language 69. 68-95.

d'Avis, Franz-Josef. 1996. On 'empty' questions. In Uli Lutz \& Gereon Müller (eds.), Papers on Wh-Scope Marking, Arbeitspapiere des Sonderforschungsbereichs 340 Sprachtheoretische Grundlagen für die Computerlinguistik, Bericht Nr. 76, 331-360. Universität Stuttgart / Universität Tübingen / IBM Deutschland.

Barbiers, Sjef. 2002. Microvariation in negation in varieties of Dutch. In Sjef Barbiers, Leonie Cornips \& Susanne van der Kleij (eds.), Syntactic Microvariation, 13-40. Amsterdam: Meertens Institute Electronic Publications in Linguistics. http://depot.knaw.nl/8460/1/ barbiers-negation.pdf (accessed 11 May 2011).

Bayer, Josef. 1996. Directionality and Logical Form. Dordrecht: Kluwer.

Bayer, Josef. 2001. Asymmetry in emphatic topicalization. In Caroline Féry \& Wolfgang Sternefeld (eds.), Audiatur Vox Sapientiae, 15-47. Berlin: Akademie Verlag.

Bayer, Josef. 2005. Wh-in-situ. In Martin Everaert \& Henk C. van Riemsdijk (eds.), The Blackwell Companion to Syntax, 376-438. Oxford: Blackwell.

Bayer, Josef. In press. From modal particle to interrogative marker: a study of German denn. To appear in Laura Brugè, Anna Cardinaletti, Giuliana Giusti, Nicola Munaro \& Cecilia Poletto (eds.), Functional Heads. Oxford: Oxford University Press.

Behaghel, Otto. 1932. Deutsche Syntax. Eine geschichtliche Darstellung, vol. IV. Heidelberg: Carl Winters Universitätsbuchhandlung.

Brody, Michael. 1997. Perfect chains. In Liliane Haegeman (ed.), Elements of grammar, 139-167. Dordrecht: Kluwer Academic Publishers.

Büring, Daniel \& Katharina Hartmann. 2001. The syntax and semantics of focus-sensitive particles in German. Natural Language and Linguistic Theory 19. 229-281. 
Cardinaletti, Anna. 2007. Für eine syntaktische Analyse von Modalpartikeln. In Eva-Maria Thüne \& Franca Ortu (eds.), Gesprochene Sprache-Partikeln, 89-101. Frankfurt: Peter Lang.

Cardinaletti, Anna. This volume. German and Italian Modal Particles and Clause Structure.

Cheng, Lisa Lai-Shen. 1991. On the Typology of Wh-Questions. Cambridge, Massachusetts: Massachusetts Institute of Technology dissertation.

Chomsky, Noam. 1995. The Minimalist Program. Cambridge, Massachusetts: MIT Press.

Chomsky, Noam. 2000. Minimalist inquiries: the framework. In Roger Martin, David Michaels, \& Juan Uriagereka (eds.), Step by Step Essays on Minimalist Syntax in Honor of Howard Las$n i k, 89-155$. Cambridge, Massachusetts: MIT Press,.

Chomsky, Noam. 2001. Derivation by phase. In Michael Kenstowicz (ed.), Ken Hale A Life in Language, 1-52. Cambridge, Massachusetts: MIT Press.

Cinque, Guglielmo. 1999. Adverbs and Functional Heads A Crosslinguistic Perspective. Oxford: Oxford University Press.

Coniglio, Marco. 2005. Deutsche Modalpartikeln eine syntaktische Analyse. Venice: University of Venice MA thesis.

Coniglio, Marco. 2008. Die Syntax der deutschen Modalpartikeln Ihre Distribution und Lizensierung in Haupt- und Nebensätzen. Venice: University of Venice dissertation.

Dasgupta, Probal. 1980. Questions and Relative and Complement Clauses in a Bangla Grammar. New York: New York University dissertation.

Dasgupta, Probal. 1984. Bangla emphasizers and anchors. Indian Linguistics 45. 102-117.

Dasgupta, Probal. 1987. Sentence particles in Bangla. In Elena Bashir, Madhav M. Deshpande \& Peter E. Hook (eds.), Selected Papers from SALA 7. Bloomington: Indiana University Linguistics Club.

Diesing, Molly. 1992. Indefinites. Cambridge, Massachusetts: MIT Press.

Diewald, Gabriele. 1997. Grammatikalisierung. Eine Einführung in Sein und Werden grammatischer Formen. Germanistische Arbeitshefte 36, Tübingen: Max Niemeyer.

Fanselow, Gisbert. 2004. Münchhausen-style head movement and the analysis of verb second. In Ralf Vogel (ed.), Three Papers on German Verb Movement. Linguistics in Potsdam 22. 9-49.

Frey, Werner. 2004. The grammar-pragmatics interface and the German prefield. Sprache und Pragmatik 52. 1-39.

Gabelentz, Georg von der. 1969 [1891]. Die Sprachwissenschaft, ihre Aufgaben und Methoden, 2nd edn. Tübingen: Narr.

Giorgi, Alessandra \& Fabio Pianesi. 1997. Tense and Aspect. From Semantics to Morphosyntax. Oxford: Oxford University Press.

Grosz, Patrick. 2005. "Dn” in Viennese German. The Syntax of a Clitic Version of the Discourse Particle “denn”. Vienna: University of Vienna Diplomarbeit.

Hack, Franziska. 2009. Syntactic Variation in Interrogatives in Romance Languages and Dialects. Konstanz: University Konstanz MA Thesis.

Haspelmath, Martin. 2002. Indefinite Pronouns. Oxford: Oxford University Press.

Hentschel, Elke. 1986. Funktion und Geschichte deutscher Partikeln. „,Ja “, ,, doch “, , halt“ und „eben ". Tübingen: Niemeyer.

Jacobs, Joachim. 1983. Fokus und Skalen Zur Syntax und Semantik der Gradpartikeln im Deutschen. Tübingen: Niemeyer.

Jacobs, Joachim. 1991. On the semantics of modal particles. In Werner Abraham (ed.), Discourse Particles, 141-162. Amsterdam: Benjamins.

Jäger, Agnes. 2005. Negation in Old High German. Zeitschrift für Sprachwissenschaft 24. 227 262.

Jayaseelan, K. A. 2001. Questions and question-word incorporating quantifiers in Malayalam. Syntax 4. 63-93. 
König, Ekkehard. 1977. Modalpartikeln in Fragesätzen. In Harald Weydt (ed.), Aspekte der Modalpartikeln, 115-130. Tübingen: Niemeyer.

Kratzer, Angelika. 1999. Beyond Ouch and Oops. How descriptive and expressive meaning interact. Handout of paper presented at the Cornell Conference on Theories of Context Dependency, Cornell University. 26 March 1999.

Kratzer, Angelika. 2004. Interpreting focus: presupposed or expressive meanings? A comment on Geurts \& van der Sandt. Theoretical Linguistics 30. 123-136.

Lechner, Winfried. 2009. A puzzle for remnant movement analyses of verb-second. Linguistic Inquiry 40. 346-356.

Löbner, Sebastian. 1990. Wahr neben falsch. Duale Operatoren als die Quantoren natürlicher Sprache. Tübingen: Niemeyer.

Matushansky, Ora. 2006. Head movement in linguistic theory. Linguistic Inquiry 37. 69-109.

Meibauer, Jörg. 1994. Modaler Kontrast und konzeptuelle Verschiebung Studien zur Syntax und Semantik deutscher Modalpartikeln. Tübingen: Niemeyer.

Müller, Gereon. 2004. Verb-second as $v$ P-first. Journal of Comparative Germanic Linguistics 7. $179-234$.

Munaro, Nicola \& Hans-Georg Obenauer. 1999. On underspecified wh-elements in pseudointerrogatives. University of Venice Working Papers in Linguistics, Vol. 9: 1-2. 181-253.

Munaro, Nicola \& Cecilia Poletto. 2003. Sentential particles and clausal typing in the Veneto dialects. University of Venice Working Papers in Linguistics, Vol. 13. 127-154.

Obenauer, Hans-Georg. 2004. Nonstandard wh-questions and alternative checkers in Pagotto. In Horst Lohnstein \& Susanne Trissler (eds.), The Syntax and Semantics of the Left Periphery, 343-383. Berlin: Mouton de Gruyter.

Obenauer, Hans-Georg. 2006. Special interrogatives - left periphery, wh-doubling, and (apparently) optional elements. In Jenny Doetjes \& Paz Gonzalves (eds.), Romance Languages and Linguistic Theory 2004 - Selected Papers from Going Romance 2004', 247-273. Amsterdam: Benjamins.

Pesetsky, David. 1987. Wh-in-situ: movement and unselective binding. In Eric Reuland \& Alice ter Meulen (eds.), The Representation of (In)definiteness, 98-129. Cambridge, Massachusetts: MIT Press.

Pesetsky, David \& Esther Torrego. 2007. The syntax of valuation and the interpretability of features. In Simin Karimi, Vida Samiian \& Wendy K. Wilkins (eds.), Phrasal and Clausal Architecture Syntactic Derivation and Interpretation, 262-294. Amsterdam: Benjamins.

Poletto, Cecilia \& Jean-Yves Pollock. 2004. On wh-clitics and wh-doubling in French and some North Eastern Italian Dialects. Probus 16.2. 241-273.

Potts, Christopher. 2005. The Logic of Conventional Implicatures. Oxford: Oxford University Press.

Potts, Christopher, Luis Alonso-Ovalle, Ash Asudeh, Rajesh Bhatt, Seth Cable, Christopher Davis, Yurie Hara, Angelika Kratzer, Eric McCready, Tom Roeper \& Martin Walkow. 2009. Expressives and identity conditions. Linguistic Inquiry 40. 356-366.

Reinhart, Tanya. 1981. Pragmatics and linguistics: An analysis of sentence topics. Philosophica 27. 53-94.

Rizzi, Luigi. 1997. The fine structure of the left periphery. In Liliane Haegeman (ed.), Elements of Grammar, 281-337. Dordrecht: Kluwer.

Rooth, Mats. 1985. Association with Focus. Amherst, MA: University of Massachusetts at Amherst dissertation.

Rothstein, Susan. 1991. Heads, projections, and category determination. In Katherine Leffel \& Denis Bouchard (eds.), Views on Phrase Structure, 97-112. Dordrecht: Kluwer.

Simpson, Andrew \& Tanmoy Bhattacharya. 2003. Obligatory overt wh-movement in a wh-in-situ language. Linguistic Inquiry 34. 127-142. 
Thurmair, Maria. 1989. Modalpartikeln und ihre Kombinationen. Tübingen: Niemeyer.

Wackernagel, Jacob. 1892. Über ein Gesetz der indogermanischen Wortstellung. Indogermanische Forschungen 1. 333-436.

Wegener, Heide. 2002. The evolution of the German modal particle 'denn'. In Ilse Wischer \& Gabriele Diewald (eds.), New Reflections on Grammaticalization, 379-393. Amsterdam: Benjamins.

Weiß, Helmut. 2002. A quantifier approach to negation in natural languages. Or why negative concord is necessary. Nordic Journal of Linguistics 25. 125-153.

Zeijlstra, Hedde. 2004. Sentential Negation and Negative Concord. Amsterdam: University of Amsterdam dissertation. Published by LOT.

Zimmermann, Malte. 2004. Zum wohl: Diskurspartikeln als Satzmodifikatoren. Linguistische Berichte 199. 253-286.

Zimmermann, Malte. 2008. Discourse Particles in the Left Periphery. In Philippa Cook, Werner Frey, Claudia Maienborn \& Benjamin Shaer (eds.) Dislocated Elements in Discourse. Oxford, Routledge, 200-231. 